\title{
Modelling developmental changes in the carbon and nitrogen budgets of larval brachyuran crabs
}

\author{
K. Anger \\ Biologische Anstalt Helgoland, Meeresstation; D-2192 Helgoland, Federal Republic of \\ Germany
}

\begin{abstract}
The uptake and partitioning of nutritional carbon $(\mathrm{C})$ and nitrogen $(\mathrm{N})$. were studied during the complete larval development of a brachyuran crab. Hyas araneus, reared under constant conditions in the laboratory. Biochemical and physiological data were published in a foregoing paper, and complete budgets of $\mathrm{C}$ and $\mathrm{N}$ were now constructed from these data. Regression equations describing rates of feeding $(F)$, growth $(G)$, respiration $(R)$, and ammonia excretion $(U)$ as functions of time during individual larval moult cycles were inserted in a simulation model, in order to analyse time-dependent (i.e. developmental) patterns of variation in these parameters as well as in bioenergetic efficiencies. Absolute daily feeding rates ( $F$; per individual) as well as carbon and nitrogen-specific rates $(F / C, F / N)$ are in general maximum in early, and minimum in late stages of individual larval moult cycles (postmoult and premoult, respectively). Early crab zoeae may ingest equivalents of up to ca $40 \%$ body $\mathrm{C}$ and $30 \%$ body $\mathrm{N}$ per day, respectively, whereas megalopa larvae usually eat less than $10 \%$. Also growth rates $(G ; G / C, G / N)$ reveal decreasing tendencies both during individual moult cycles and, on the average, in subsequent instars. Conversion of $C$ and $\mathrm{N}$ data to lipid and protein, respectively, suggests that in all larval ínstars there is initially an increase in the lipid:protein ratio. Protein, however, remains clearly the predominant biochemical constituent in larval biomass. The absolute and specific values of respiration $(R ; R / C)$ and excretion $(U ; U / \mathrm{N})$ vary only little during the course of individual moult cycles. Thus, their significance in relation to $G$ increases within the $\mathrm{C}$ and $\mathrm{N}$ budgets, and net growth efficiency $\left(K_{2}\right)$ decreases concurrently. Also gross growth and assimilation efficiency $\left(K_{2} ; A / F\right)$ are, in general, maximum in early stages of the moult cycle (postmoult). Biochemical data suggest that lipid utilization efficiency is particularly high in early moult cycle stages, whereas protein utilization efficiency is higher in later stages. Only the zoea II appears to accumulate lipid from food constantly with a higher conversion efficiency than protein. The cumulative $C$ and $N$ budgets show in subsequent larval instars conspicuously increasing figures in all of their parameters. $F$ and $G$ increase to a particularly high extent from the first to the second zoeal instar, whereas $R, U$, exuvia production $\left(G_{E}\right)$, and total assimilation $(A)$ reveal a greater increase from the zoea II to the megalopa. Respiratory, excretory, and exuvial losses increase in subsequent larval instars at higher rates than tissue growth and, hence, $K_{2}$ decreases in the same order. In the C budget, $K_{2}$ values of 0.63 (zoea I), 0.56 (zoea II), and 0.29 (megalopa) were calculated (or: $0.56,0.46$, and 0.16 after subtraction of exuviae). In the $\mathrm{N}$ budget, corresponding values of 0.76 , 0.66 , and 0.45 (or: $0.72,0.62,0.38$ without exuviae) were obtained. Also $K_{1}$ decreases slightly in subsequent instars, whereas $A / F$ reveals rather an increasing tendency, at least from the zoeal instars to the megalopa. Changes in the uptake and partitioning of matter in crab larvae are discussed in relation to developmental events and changes in life style before metamorphosis.
\end{abstract}

\section{INTRODUCTION}

Bioenergetic aspects of larval development have been investigated during the past decade in an increasing number of decapod crustacean species. The green crab (Car- 
cinus maenas; Dawirs et al., 1986), the mud crab (Rhithropanopeus harrisii; Levine \& Sulkin, 1979), the rock crab (Cancer irroratus; Johns, 1982), the American lobster (Homarus americanus; Logan \& Epifanio, 1978; Sasaki et al., 1986), and the spider crab (Hyas araneus; Anger et al., 1989) may be considered model species for such studies. In the last mentioned paper, biochemical and physiological data were reviewed that had been obtained during the past ten years in a number of investigations with $H$. araneus larvae. These data are used in the present paper for modelling changes in the carbon and nitrogen budgets during the course of complete development, from hatching to metamorphosis. Since all cultivation experiments were conducted in the laboratory under constant environmental conditions, bioenergetic changes may be considered the result of exclusively developmental events such as individual larval moult cycles, settlement, and metamorphosis. The present paper is an attempt to provide a testable model of developmental changes in the uptake and partitioning of matter in brachyuran larvae.

\section{MATERIALS AND METHODS}

Larvae of Hyas araneus were reared in the laboratory under constant conditions $\left(12{ }^{\circ} \mathrm{C} ;\right.$ ca $32 \% \mathrm{~S}_{i}$ Artemia spec. nauplii given as food), and their ingestion rate, growth (dry weight, carbon, nitrogen, hydrogen, protein, lipid), respiration, and ammonia excretion were measured in regular intervals of time from hatching to metamorphosis. Rearing techniques, moult staging, and analytical procedures were referred to in detail by Anger et al. (1989), who also documented the biochemical and physiological results used in the present paper.

Regression equations describing growth, respiration, and excretion were obtained from one experiment conducted with larvae hatched from the same female, those on ingestion from another hatch (Anger et al., 1989). Data on exuvial losses (Table 1) were taken from Anger (1984). Regression equations and fitted constants were inserted in a Stella ${ }^{\mathrm{TM}}$ simulation model, and simulations were run on a MacIntosh ${ }^{\mathrm{TM}}$ Plus (Apple ${ }^{\circledR}$ ) computer.

\section{THE MODEL}

The uptake and partitioning of nutritional materials can be described by the following general equations (Ivlev, 1945; Warren \& Davis, 1967):

$$
\begin{aligned}
& G=G_{T}+G_{E}=F-L-R-U \\
& A=G+R+U=F-L \\
& K_{1}=G / F \\
& K_{2}=G / A
\end{aligned}
$$

where:

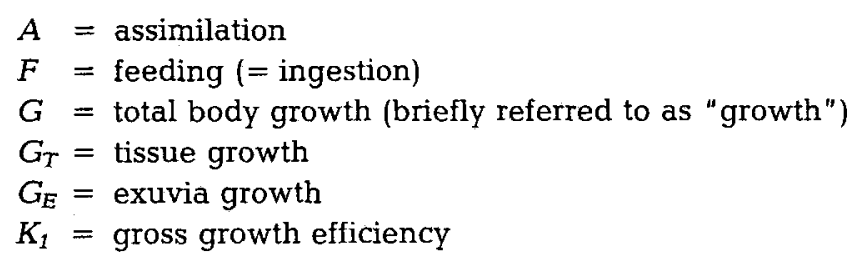


$K_{2}=$ net growth efficiency

$L=$ sum of losses by defaecation and leaching (loss of small particles and liquids from food, due to inefficient feeding mechanisms)

$R=$ respiration

$U=$ excretion of ammonia nitrogen

Eqs. (1) and (2) are in the present form (containing both $R$ and $U$ ) valid only for an energy budget. Since no urea was measured, and ammonia was found to be the only significant excretory nitrogen compound in Hyas araneus larvae (Anger et al., 1989), the term $U$ does not apply to the carbon budget, whereas $R$ does not occur in the nitrogen budget.

The following average development durations $\left(D\right.$, in days; at $\left.12^{\circ} \mathrm{C}\right)$ were used as simulation periods:

Zoea I $\quad: D=11 \mathrm{~d}$

Zoea II $: D=12 \mathrm{~d}$

Megalopa : $D=24 \mathrm{~d}$

The simulation of absolute changes in the carbon and nitrogen budgets during time ( $t$, in days) of development is based on the following principal regression equations (dimensions: $\mu \mathrm{g} \mathrm{C} \cdot$ individual $^{-1} \cdot \mathrm{d}^{-1}$, or $\mu \mathrm{g} \mathrm{N} \cdot$ individual ${ }^{-1} \cdot \mathrm{d}^{-1}$, respectively):

\section{Feeding rate}

Zoea I $\quad: F=12.1+1.22 \cdot t-0.114 \cdot t^{2}$

Zoea II $\quad: F=31.5+0.81 \cdot t-0.194 \cdot t^{2}$

Megalopa : $F=25.4 \cdot \mathrm{e}^{-0.0496 \cdot t \cdot}$

Eqs. (5) to (7) refer to consumption of numbers of Artemia nauplii. They have to be multiplied with average $\mathrm{C}$ and $\mathrm{N}$ contents of the nauplii (Anger et al., 1989), respectively:

$0.77 \mu \mathrm{g} \mathrm{C}$ - individual ${ }^{-1}$ for the carbon budget,

$0.14 \mu \mathrm{g} \mathrm{N} \cdot$ individual $^{-1}$ for the nitrogen budget.

Specific feeding rates $(F / C, F / N)$ are related to biomass units and hence are obtained by dividing Eqs. (5), (6), or (7) by $\mathrm{C}$ or $\mathrm{N}$, respectively.

Ingestion of lipid and protein may be estimated by multiplication of the number of individuals (Artemia nauplii) consumed with the following conversion factors:

$0.36 \mu \mathrm{g}$ lipid · individual ${ }^{-1}$,

$0.82 \mu \mathrm{g}$ protein $\cdot$ individual $^{-1}$.

These factors were obtained from $\mathrm{C}$ and $\mathrm{N}$ contents (see above), respectively, using the following regression equations (Anger et al., 1989):

Lipid $=0.46 \cdot \mathrm{C}^{0.947}\left[\mu \mathrm{g} \cdot\right.$ individual $\left.^{-1}\right]$

Protein $=5.20 \cdot \mathrm{N}^{0.941}\left[\mu \mathrm{g} \cdot\right.$ individual $\left.^{-1}\right]$

Very similar values may be calculated from the percentage lipid and protein figures given by Seidel et al. (1982), Watanabe et al. (1983), Katavic et al. (1985), or SumitraVijayaraghavan \& Royan (1988) for San Francisco Artemia, and a naupliar dry weight of 
$1.57 \mu \mathrm{g} \cdot$ individual $^{-1}$ (Anger et al., 1989); the latter value is close to that given by Sorgeloos et al. (1983): $1.63 \mu \mathrm{g} \cdot$ individual $^{-1}$.

\section{Growth rate}

Instantaneous absolute growth rates (dimension: $\mu \mathrm{g} \cdot$ individual $^{-1} \cdot \mathrm{d}^{-1}$ ) were obtained by differentiation of the regression equations given by Anger et al. (1989) for biomass ( $\mathrm{C}$ or $\mathrm{N}$, respectively):

Zoea I:

$G=\mathrm{dC} / \mathrm{d} t=9.50 \cdot(t+1)^{-0.562}$

$G=\mathrm{dN} / \mathrm{d} t=$ const. $=0.716$

Zoea II:

$G=\mathrm{dC} / \mathrm{d} t=18.17 \cdot(t+1)^{-0.713}$
$G=\mathrm{dN} / \mathrm{d} t=3.06 \cdot(t+1)^{-0.768}$

Megalopa:

$G=\mathrm{dC} / \mathrm{d} t=13.47-0.863 \cdot t$

$G=\mathrm{dN} / \mathrm{d} t=2.19-0.125 \cdot t$

Eqs. (8) and (9) can also be used to convert elemental ( $C, N)$ to biochemical (lipid, protein) growth data, by substituting them into the $\mathrm{C}$ and $\mathrm{N}$ growth equations (Eqs. 10 to 15), respectively.

Specific growth rates are obtained by appropriate division of Eqs. (10) to (15):

$G / C=\mathrm{dC} / \mathrm{C} \cdot \mathrm{d} t$

$\mathrm{G} / \mathrm{N}=\mathrm{dN} / \mathrm{N} \cdot \mathrm{d} t$

\section{Respiration rate}

Respiratory carbon losses were calculated by multiplying regression equations for oxygen consumption (Anger et al., 1989) with factors of 24 (conversion to daily rates) and $0.3375 \mu \mathrm{g} \mathrm{C} / \mu \mathrm{gO}_{2}$. The latter conversion factor is based on an average $\mathrm{RQ}=0.9$, which may be assumed from the biochemical composition of both the larvae (Anger et al., 1989) and their food (e.g. Watanabe et al., 1983; Sumitra-Vijayaraghavan \& Royan, 1988). Similar RQ values were assumed also in studies on other crustaceans (see e.g. Nelson et al., 1977, for discussion).

Zoea I:

$R=1.47+0.147 \cdot t$

Zoea II:

$R=4.15+0.0564 \cdot t$

Megalopa:

$R=7.05-0.401 \cdot t+0.0526 \cdot t^{2}-0.00141 \cdot t^{3}$

Carbon-specific respiration rates $(R / \mathrm{C})$ are obtained in the same way as the corresponding specific feeding rates: dividing Eqs. (18) to (20) by $C$. 


\section{Excretion rate}

Excretory nitrogen losses were obtained from the regression equations given by Anger et al. (1989), after conversion to daily rates $(\times 24)$ and from $\mathrm{ng}$ to $\mu \mathrm{g}$ units $(\times 0.001)$.

\section{Zoea I:}

$U=0.114+0.0460 \cdot t-0.00360 \cdot t^{2}$

Zoea II:

$U=0.207+0.1140 \cdot t-0.00876 \cdot t^{2}$

Megalopa:

$U=0.487+0.0735 \cdot t-0.00274 \cdot t^{2}$

Nitrogen-specific excretion rate $(U / N)$ is calculated by division of Eqs. (21) to (23) by $\mathrm{N}$.

\section{Exuvia production}

Production of exuviae was calculated only for summary budgets, assuming constant losses of late premoult carbon and nitrogen, respectively (Table 1) and applying them to simulated final biomass values.

Table 1. Hyas araneus. Percentage of late premoult carbon (C) and nitrogen (N) lost with shed exuviae (recalculated from Anger, 1984)

\begin{tabular}{|cccc|}
\hline & Zoea I & Zoea II & Megalopa \\
\hline C (\%) & 7.73 & 8.71 & 16.38 \\
N $(\%)$ & 3.08 & 2.82 & 5.83 \\
\hline
\end{tabular}

Loss

Losses (L) by defaecation and leaching were estimated by difference from the remaining budget parameters (Eqs. 1,2).

\section{RESULTS}

\section{Instantaneous carbon and nitrogen budgets}

The absolute values (dimension: $\mu \mathrm{g} \cdot$ individual ${ }^{-1} \cdot \mathrm{d}^{-1}$ ) of feeding $(F)$, growth $(G$ ), respiration $(R)$, excretion $(U)$, and assimilation $(A)$ show conspicuous variations during individual larval moult cycles, with mostly similar patterns in the carbon and nitrogen budgets (Figs 1,2). Food uptake reaches maxima approximately in the middle of the zoea I moult cycle (during stages $D_{0}$ to $D_{2}$ of Drach's classification system; cf. Drach, 1939), earlier during the zoea II (during stages $B$ to $D_{0}$ ), and in the beginning (stages $B$ to early C) of the megalopa moult cycle. 

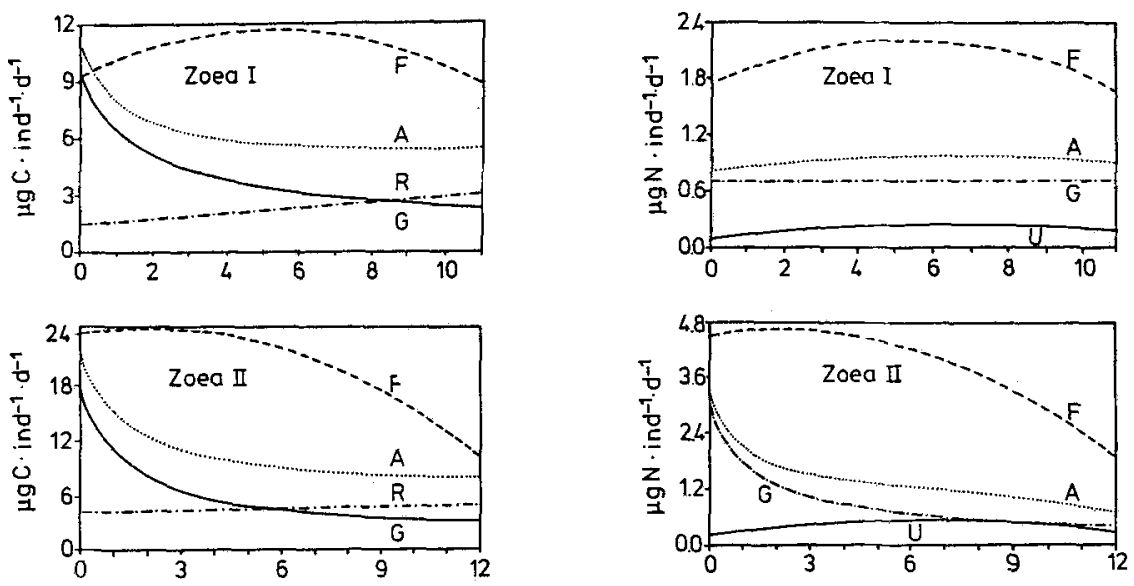

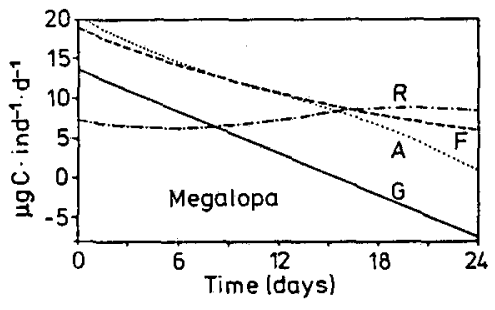

Fig. 1

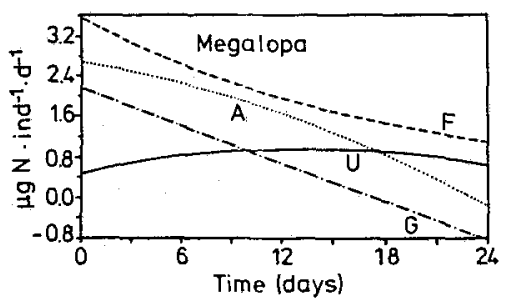

Fig. 2

Fig. 1. Hyas araneus, larval instars, carbon (C) budget. Instantaneous individual rates of feeding (F), assimilation (A), respiration $(R)$, and growth $(G)$, in relation to time (d) of development; unit: $\mu \mathrm{g} \mathrm{C} \cdot$ individual $^{-1} \cdot \mathrm{d}^{-1}$

Fig. 2. Hyas araneus, larval instars, nitrogen $(\mathrm{N})$ budget. Instantaneous individual rates of feeding $(F)$, assimilation (A), excretion (U), and growth (G), in relation to time (d) of development; unit: $\mu \mathrm{g} N \cdot$ individual $^{-1} \cdot \mathrm{d}^{-1}$

Growth rates are in almost all instars maximum in the postmoult and early intermoult stages $(\mathrm{A}-\mathrm{C})$. They decrease throughout the rest of the moult cycle and so reach a minimum in late premoult $\left(D_{2}-D_{4}\right)$. The only exception is nitrogen accumulation in the zoea I, where biomass was observed to increase in a linear way (Anger et al., 1989) and thus, the model assumes constant daily growth rates (Eq. 11; Fig. 2). In the megalopa, $G$ decreases as a linear function of time and becomes negative during premoult.

Different growth patterns in the carbon and nitrogen budgets presumably reflect biochemical changes in larval biomass. Therefore, larval lipid and protein contents were calculated from $C$ and $N$ values (Eqs. 8 and 9). Simulated changes in these two predominant biochemical constituents are shown in Figure 3, and their instantaneous growth rates in Figure 4. These curves suggest that the larvae in general not only contain but also accumulate higher absolute quantities of protein than lipid (per individual and day). However, specific (= relative) accumulation rates (related to weight units of protein and lipid bound already in larval biomass) change during each moult cycle and from instar to instar, so that also the lipid:protein ratio changes significantly in the larval body 

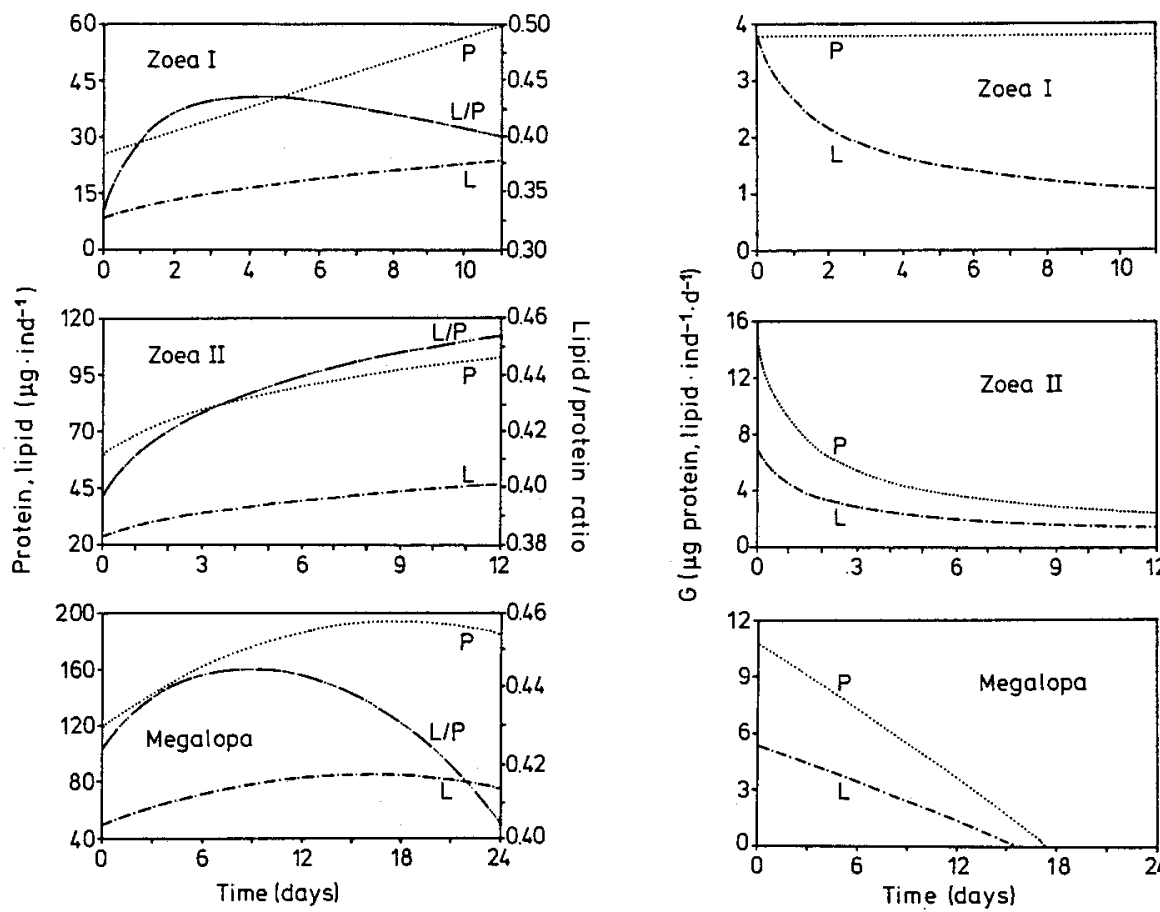

Fig. 3
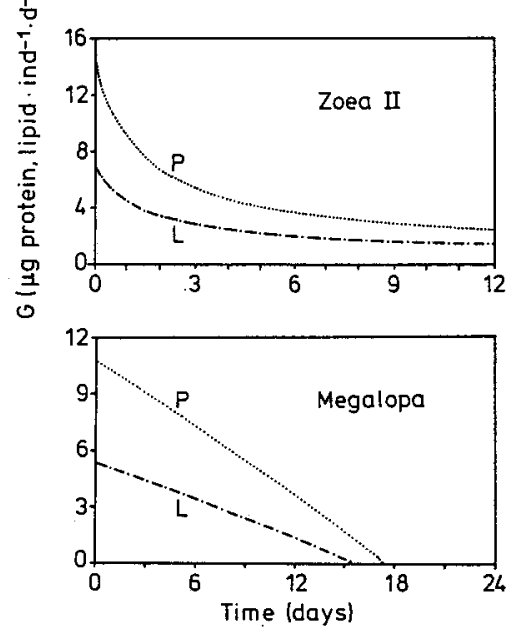

Fig. 4

Fig. 3. Hyas araneus, larval instars. Lipid (L) and protein (P) content $\left(\mu \mathrm{g} \cdot\right.$ individual $\left.^{-1}\right)$, and $\mathrm{L} / \mathrm{P}$ weight ratio in relation to time (d) of development ( $L, P$ calculated from $C$ and $N$; Eqs. 8, 9)

Fig. 4. Hyas araneus, larval instars. Instantaneous individual growth rates $(G)$ in lipid (L) and protein (P), in relation to time (d) of development; $L, P$ calculated from $C$ and $N$ (Eqs. 8, 9); units: $\mu$ g lipid, protein $\cdot$ individual $^{-1} \cdot \mathrm{d}^{-1}$

(Fig.3): according to this index, the early stages of the moult cycle (postmoult, early intermoult) are characterized by particularly high specific lipid accumulation rates, whereas in later stages proportionately more protein may be stored per unit of time. Prior to metamorphosis, the megalopa loses fractions of both constituents, but in different proportions: a decreasing lipid:protein ratio (Fig. 3) indicates that a higher percentage of previously stored lipid is lost, as compared to protein.

Respiration and ammonia excretion remain relatively constant during each moult cycle. Since growth rate decreases in most cases, $R$ and $U$ become increasingly important parameters of the carbon and nitrogen budgets, respectively (Figs 1,2). $R$ increases during the zoeal instars in a linear way, whereas in the megalopa it shows a sinusoidal variation pattern (Fig. 1). $U$, in contrast, is maximum near the middle of each moult cycle (Fig. 2). The average levels of both $R$ and $U$ increase conspicuously from instar to instar. The patterns of change in total assimilation $(A)$ are in general dictated mainly by those in growth (Figs 1, 2).

Figures 5 and 6 show variations in the relative values (per unit of biomass) of $F, G, R$, 

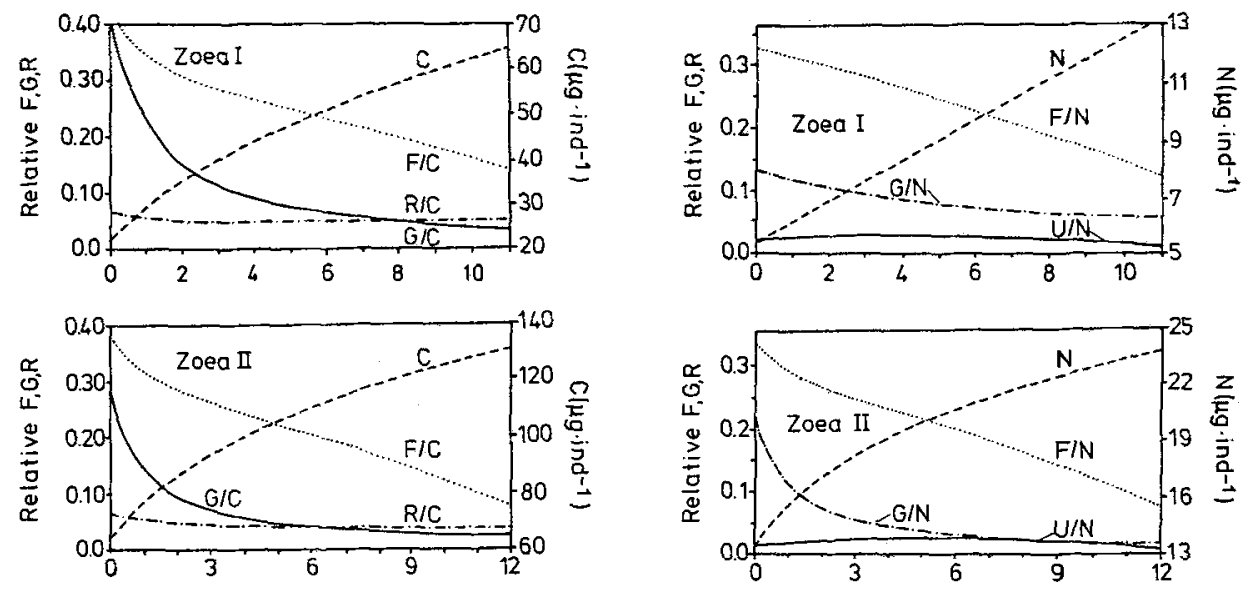

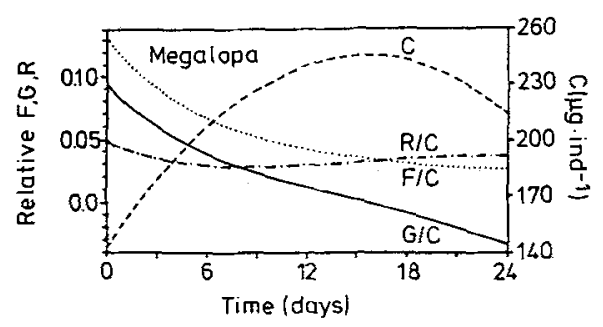

Fig. 5

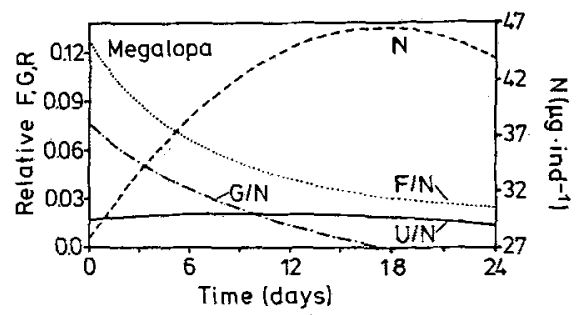

Fig. 6

Fig. 5. Hyas araneus, larval instars, carbon (C) budget. $\mathrm{C}$ content ( $\mu \mathrm{g} \cdot$ individual $^{-1}$ ); instantaneous relative (C-specific) rates of feeding $(F / C)$, respiration $(R / C)$, and growth $(G / C)$, in relation to time (d) of development; unit: fraction of body $C \cdot d^{-1}$

Fig. 6. Hyas araneus, larval instars, nitrogen $(\mathrm{N})$ budget. $\mathrm{N}$ content ( $\mu \mathrm{g} \cdot$ individual $^{-1}$ ); instantaneous relative $(\mathrm{N}$-specific) rates of feeding $(F / N)$, excretion $(U / N)$, and growth $(G / N)$, in relation to time (d) of development; unit: fraction of body $\mathrm{N} \cdot \mathrm{d}^{-1}$

and $U$; changes in the reference constituents for biomass $(\mathrm{C}, \mathrm{N})$ are shown in the same graphs.

Specific feeding rates are in general higher in the carbon budget $(F / C ; F i g .5)$ than in the nitrogen budget $\left(F / N_{i}\right.$ Fig. 6$)$, and they show decreasing tendencies during subsequent moult cycles. Maximum values $(F / C \approx 0.4$ and $F / \mathrm{N} \approx 0.3)$ are found in early stages (postmoult) of the zoeal instars. Late premoult zoeae and megalopa larvae, in contrast, have specific feeding rates of only $\approx 0.1$ or less (Figs 5,6 ).

Also specific growth rates (Eqs. 16,17) show in general a higher level in carbon (G) C) than in nitrogen $(G / N)$ and decreasing tendencies during development (Figs 5, 6). The degree of variation is much higher in $G / C$ than in $G / N$, with maximum $G / C \approx 0.4$ (early zoea I) and $G / N \approx 0.2$ (early zoea II), and minimum values (in late premoult) approaching zero (zoeal instars) or becoming negative (megalopa).

Specific rates of respiration $\left(R / C_{;}\right.$Fig. 5$)$ and excretion (U/N; Fig.6) vary only relatively little during individual moult cycles. Thus, the relative significance of both $R$ and $U$ within the carbon and nitrogen budgets, respectively, increases in relation to 
growth, often outbalancing it in late premoult (Figs 5,6 ). $R / C$ values are in general $\leq 0.05$, and $U / \mathrm{N} \leq 0.03$.

The increase of $R$ during each moult cycle and in subsequent instars in relation to other parameters of the carbon budget, can be seen also in the metabolic coefficient, i.e.
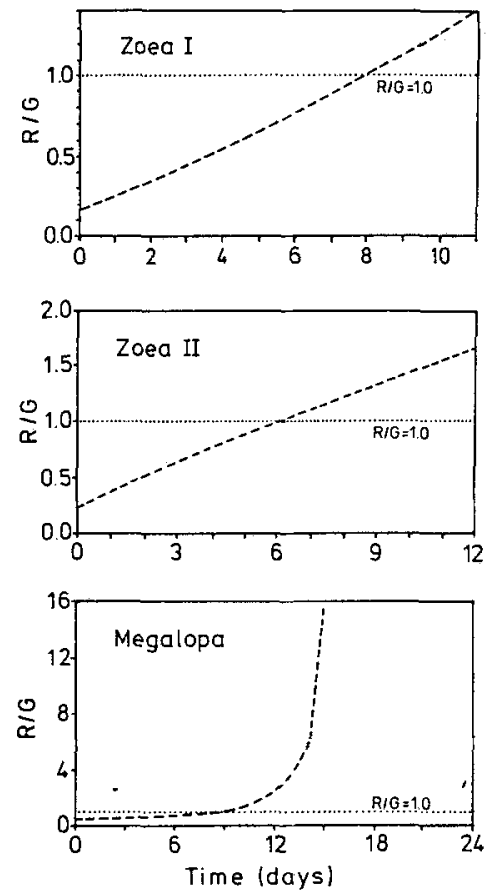

Fig. 7. Hyas araneus, larval instars, carbon (C) budget. Metabolic coefficient $(R / G)$, in relation to time (d) of development; unit of $R, \mathrm{G}: \mu \mathrm{g} \mathrm{C} \cdot$ individual $^{-1} \cdot \mathrm{d}^{-1}$

the portion of metabolizable $\mathrm{C}$, that is respired $(R / G ;$ Fig. 7). $R / G$ is $<1$ (i.e. $R<G$ ) in each postmoult phase, then it increases and becomes $>1(R>G)$. From instar to instar, equality $(R / G=1)$ is reached earlier, and the average level in $R / G$ increases (Fig. 7). The metabolic coefficient is inversely related to net growth efficiency $\left(K_{2}\right)$ :

$$
R / G=\frac{1}{K_{2}}-1
$$

Hence, $K_{2}$ shows, during development, tendencies opposite to those in $R / G$. Variation in $K_{2}$ is usually parallelled by that in gross growth efficiency $\left(K_{1} ;\right.$ Figs 8,9$)$. Growth efficiencies are in general maximum in early postmoult, then they decrease to a minimum in intermoult or premoult.

Assimilation efficiency $(A / F)$ shows in the zoeal instars a minimum near the middle of the moult cycle (intermoult, early premoult). During megalopa development, it remains high during the first half of the moult cycle, before it declines drastically prior to metamorphosis (Figs 8,9), $A / F$ is, on the average, higher in $\mathrm{C}$ than in $\mathrm{N}$. 

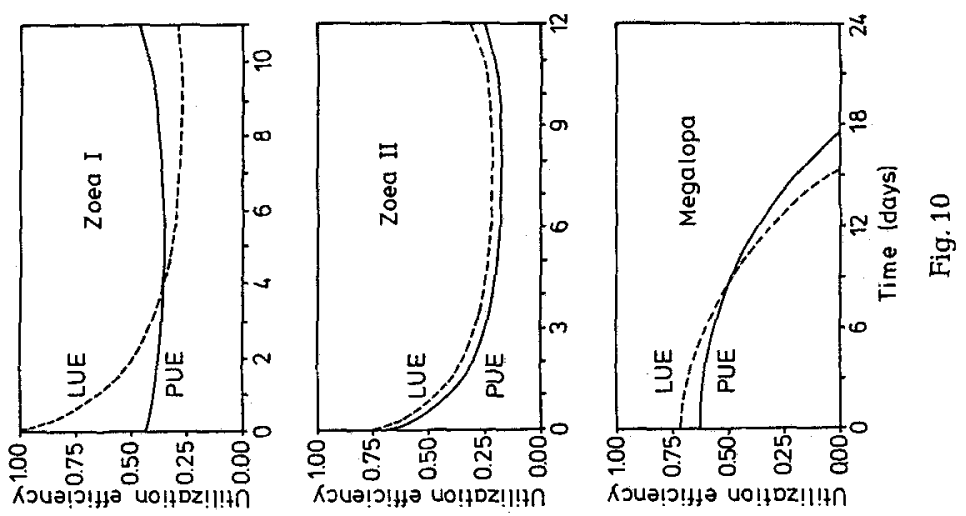

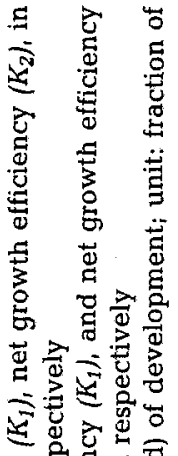

훙 记要

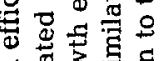

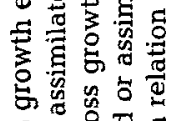
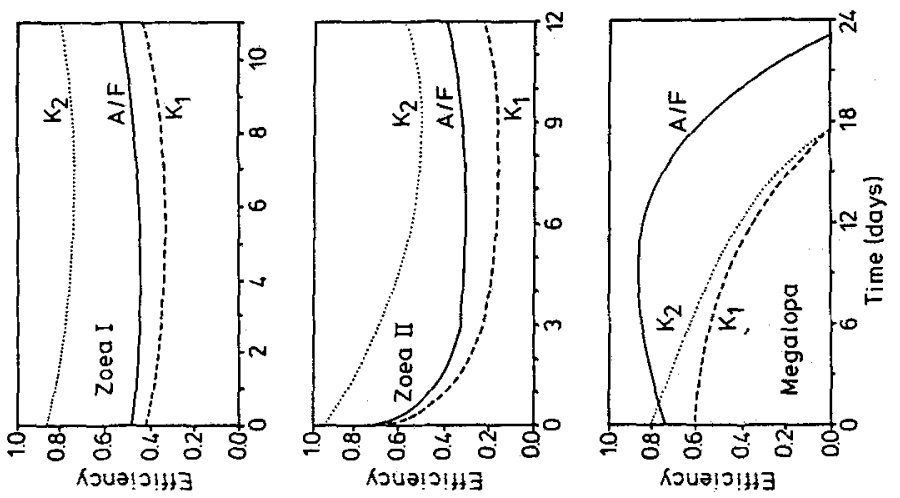

영 형

它可要田?

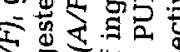

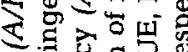

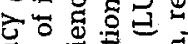

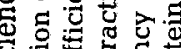

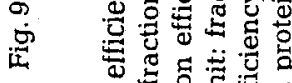

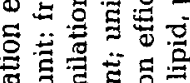

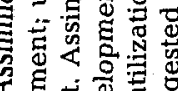

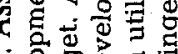

过宽要

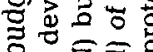

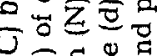

可 둥
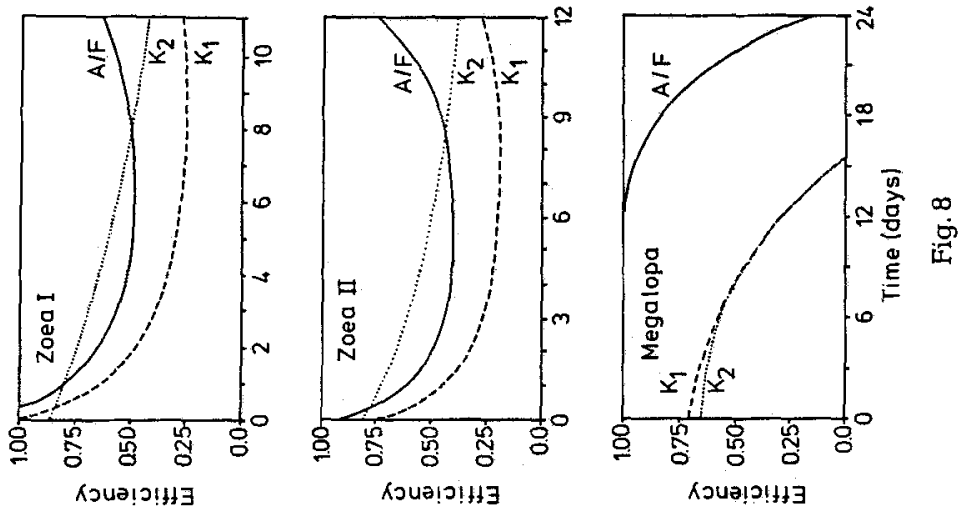

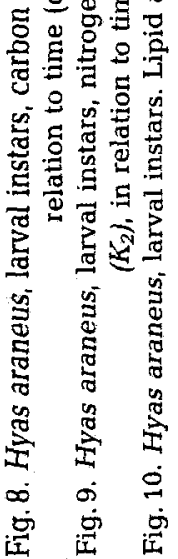


The efficiencies shown in Figures 8 and 9 refer to conversion of total $\mathrm{C}$ and $\mathrm{N}$, respectively. From these data, protein and lipid utilization efficiencies may be obtained (Eqs. 8, 9). These biochemical efficiencies (Fig. 10) suggest that the relatively high lipid accumulation rates observed during early moult cycle stages may be caused by particularly high lipid utilization efficiencies. In contrast, conversion of ingested protein appears to be more efficient in the premoult stages, at least in the zoea I and megalopa instars. In the zoea II, lipid utilization efficiency is constantly somewhat higher than that of protein (Fig. 10), resulting in a steadily increasing lipid: protein ratio during this instar (Fig. 3).

The amounts of $\mathrm{C}$ and $\mathrm{N}$ ingested but not assimilated, i.e. total loss $(L)$ was not measured. Since it is theoretically represented by the difference $F-A$ (Eq. 2), its absolute quantity ( $\mu \mathrm{g} \cdot$ individual ${ }^{-1} \cdot \mathrm{d}^{-} 1$ ) appears in Figures 1 and 2 as a gap between the $F$ and $A$ curves. According to this, $L$ is high in the zoeal instars, with maximum values approximately in the middle of the moult cycle (intermoult, early premoult), but very low in the megalopa. Specific loss is represented by:

$$
L / F=1-A / F
$$

Thus, it can be seen as the area above the $A / F$ curves in Figures 8 and $9 . L / F$ shows approximately the same patterns as absolute $L$, with maximum values in the middle of the zoeal moult cycles and at the end of larval development, near metamorphosis.

\section{Interrelationships between budget parameters measured during individual moult cycles}

When absolute or specific parameters of the carbon or nitrogen budgets $(F, G, R, U$, efficiencies) are plotted against eaçh other or against biomass $(C, N)$, in most instances no direct relationships can be detected. Figure 11 shows, as an example, carbon-specific $F$, $G$, and $R$ values plotted against biomass carbon. In the zoeal instars, negative relationships seem to exist; however, the curves obtained from megalopa data suggest that both parameters are actually regulated independently by a third variable: the moult cycle. Thus, parameters of the carbon and nitrogen budgets cannot be predicted directly from each other or from biomass, unless the stage of the moult cycle is also considered.

The only exception, both in the carbon and nitrogen budgets, may be a positive correlation between specific growth and specific feeding rates (Fig. 12). Again, this possible relationship is modified by the moult cycle, which probably causes the nonlinearity seen in Figure 12.

\section{Cumulative carbon and nitrogen budgets of single larval instars and for com-} plete larval development

Cumulative budget parameters are obtained by integration over time of development $(t=0 \ldots D)$ of Eqs. 5 to $7(F), 10$ to $15(G), 18$ to $20(R)$, and 21 to $23(U)$. All these cumulative parameters increase conspicuously from instar to instar (Figs 13, 14). In assimilation (A), exuvia production $\left(G_{E}\right), R$, and $U$, the increase is exponential, whereas $F$ and tissue growth $\left(G_{T}\right)$ show a similar strong increase only from the first to the second zoeal instar. The megalopa ingests in total only little more than the zoea II, although its development duration is about twice as long (see above). 

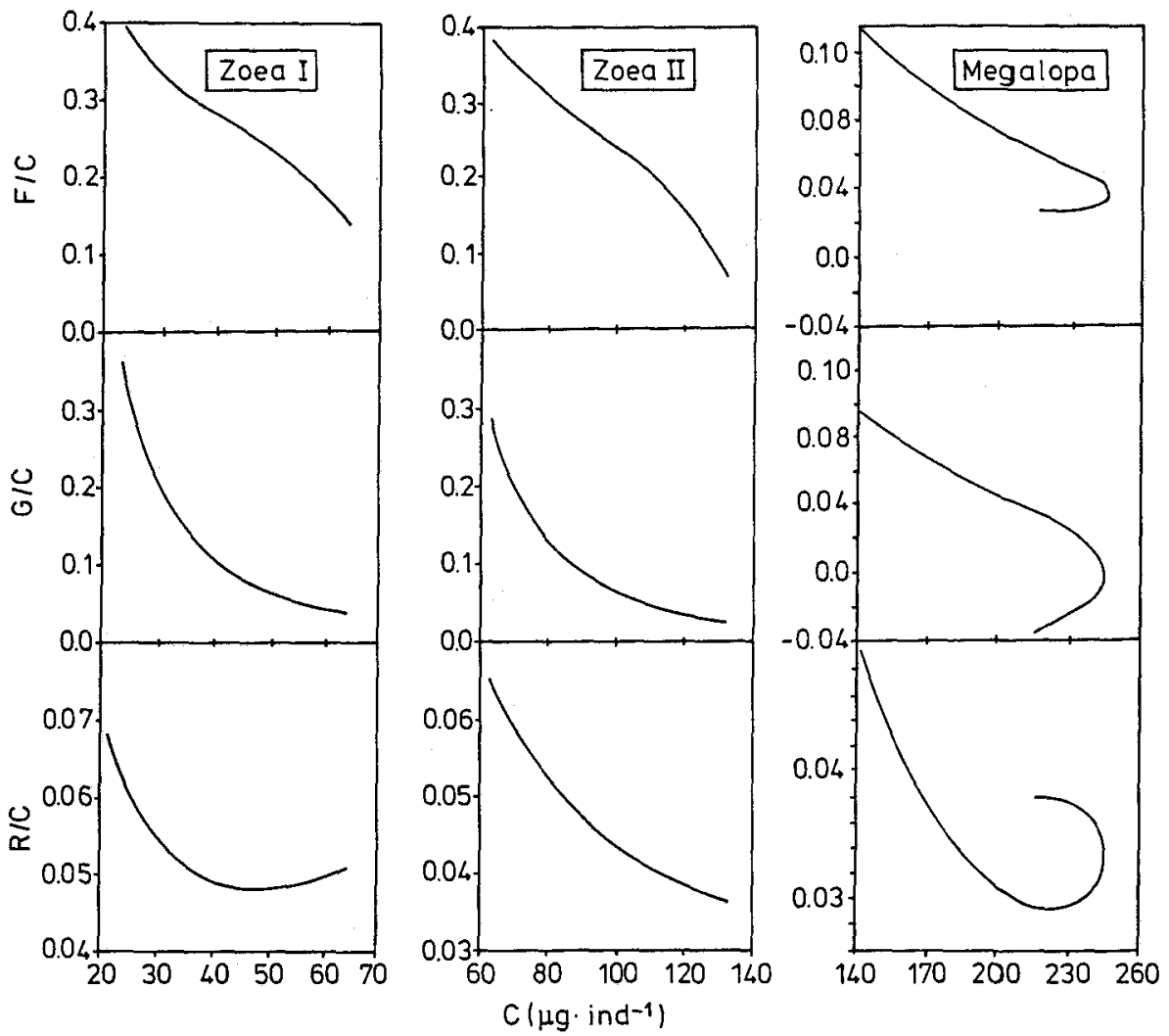

Fig. 11. Hyas araneus, larval instars, carbon (C) budget. Relative (C-specific) rates of feeding $(F / C)$, growth $(G / C)$, and respiration $(R / C)$ (unit: fraction of body $\left.C \cdot \mathrm{d}^{-1}\right)$ plotted against biomass $(\mu \mathrm{g}$ $\mathrm{C} \cdot$ individual $^{-1}$ )
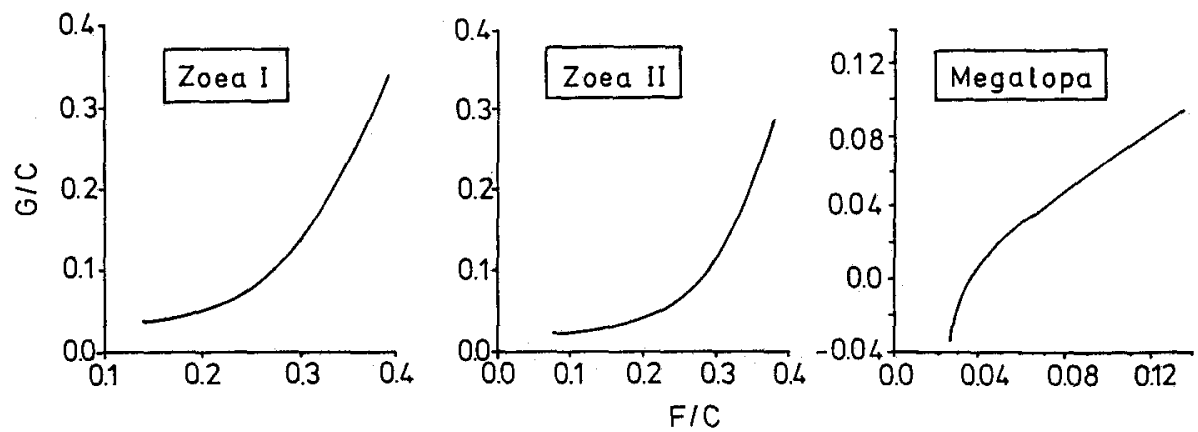

Fig. 12. Hyas araneus, larval instars, carbon (C) budget. Relative (C-specific) rate of growth $(G / C)$ plotted against $\mathrm{C}$-specific rate of feeding $(F / C)$ (unit: fraction of body $\mathrm{C} \cdot \mathrm{d}^{-1}$ ) 

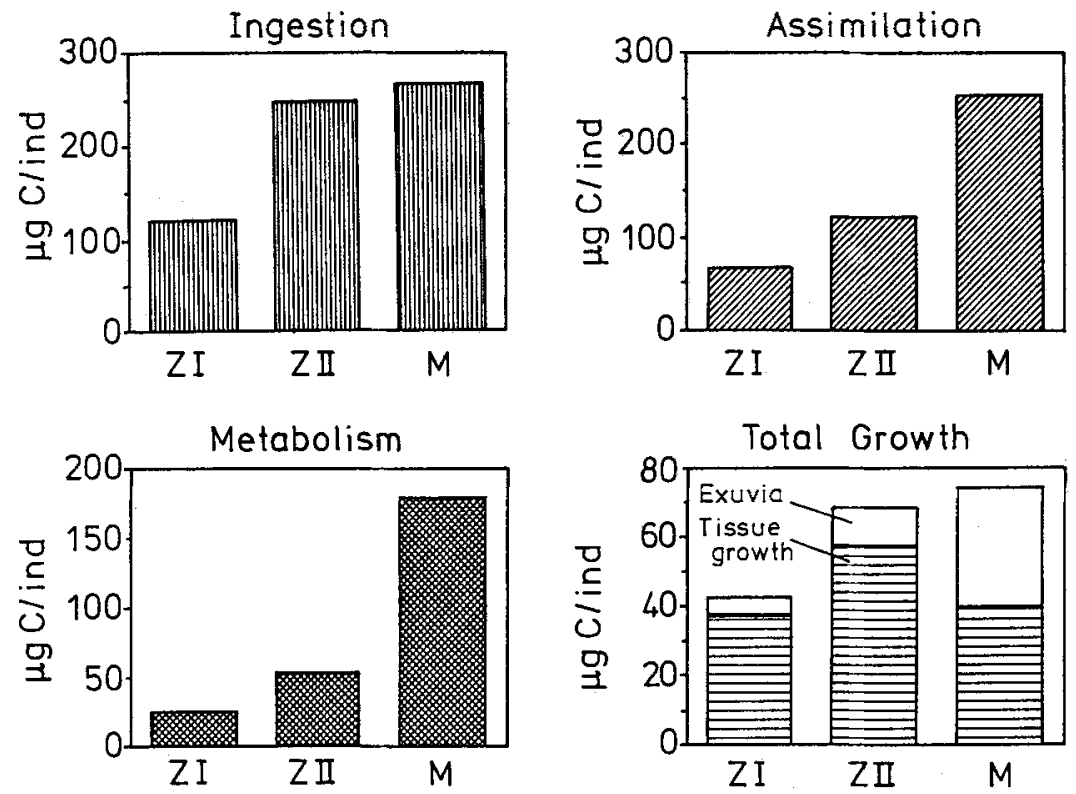

Fig. 13. Hyas araneus, larval instars, carbon $(C)$ budget. Cumulative values ( $\mu \mathrm{g} C \cdot$ individual $^{-1}$ ) of ingestion $(F)$, assimilation $(A)$, metabolism (= respiration, $R$ ), and growth (total growth, $G$; tissue growth, $G_{T}$; exuvia production, $\left.G_{E}\right)$
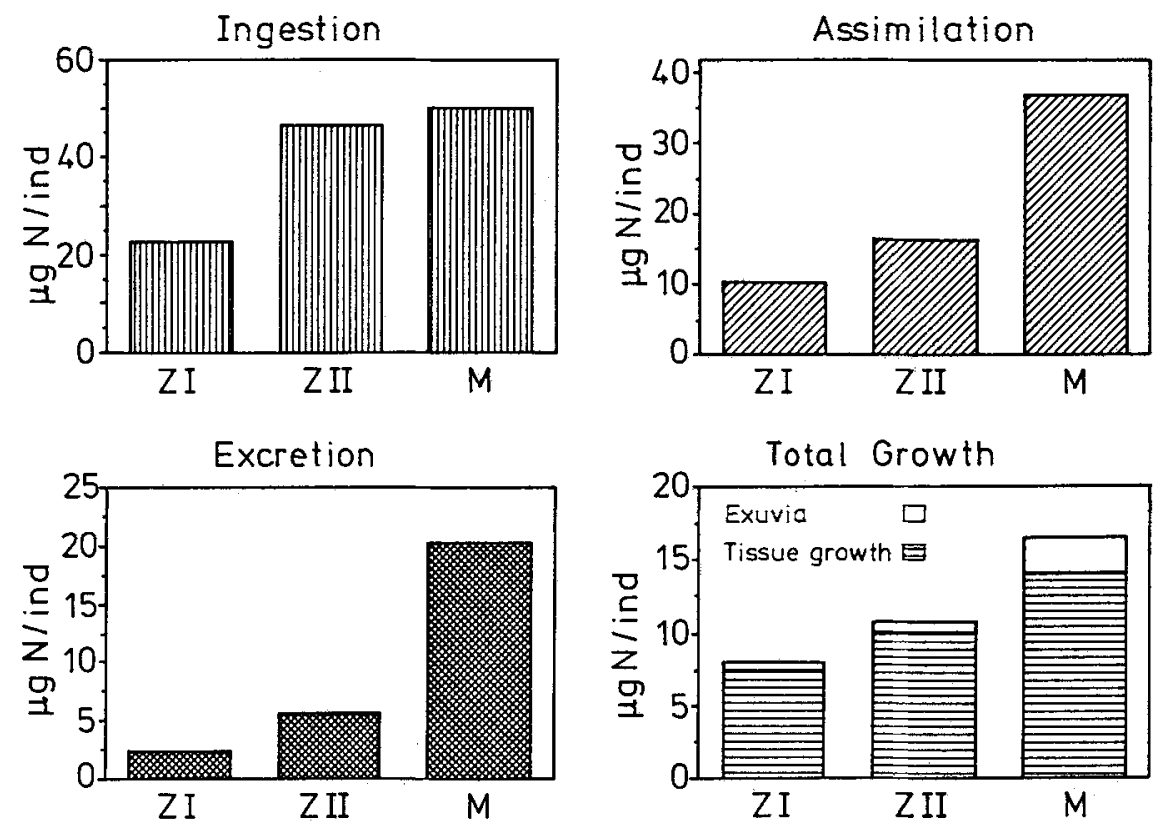

Fig. 14. Hyas araneus, larval instars, nitrogen (N) budget. Cumulative values $\left(\mu \mathrm{g} \mathrm{N} \cdot\right.$ individual $\left.^{-1}\right)$ of ingestion $(F)$, assimilation $(A)$, excretion $(U)$, and growth (total growth, $G$; tissue growth, $G_{T}$; exuvia production, $G_{E}$ ) 
Cumulative tissue growth $\left(G_{T}\right)$ of the megalopa differs in the carbon and nitrogen budgets: while nitrogen accumulation increases constantly during larval development, carbon accumulation in the megalopa is less than in the zoea II and only little more than in the zoea I (Figs 13,14). This effect is caused by high carbon and low nitrogen content of its heavy exuvia, which has to be substracted from total growth figures.

Figures 15 and 16 show the percentage contribution of each of the three larval instars to the complete carbon and nitrogen budgets (from hatching to metamorphosis). With the exception of tissue carbon accumulation $\left(G_{T}, C_{i}\right.$ Fig. 15), the percentage contribution by each instar increases during larval development from the zoea I to the megalopa. This is particularly obvious in respiration (Fig. 15), excretion (Fig. 16), and exuvia production (Figs 15,16 ). In these three parameters, the megalopa instar is responsible for more than two thirds of the cumulative values for complete larval development.

Specific differences among the larval instars in their partitioning of carbon and nitrogen can be seen in Figures 17 and 18. Total loss $(L)$ by defaecation and leaching is in general greater in $\mathrm{N}$ than in $\mathrm{C}$, and it is much less in the megalopa than in the zoeal instars. Respiration and excretion increase from the first to the last larval instar both in absolute and relative ( $\%$ of total ingestion) terms, whereas the percentage of ingested $\mathrm{C}$ and $\mathrm{N}$ that is channelled into growth (i.e. gross growth efficiency, $K_{1}$ ) remains more or less constant or decreases slightly.

When $L$ is disregarded and exclusively the partitioning of assimilated carbon and nitrogen is considered, some specific differences between single instars become more conspicuous (Figs 19,20). The fraction of assimilated matter that is channelled into tissue growth $\left(G_{T}\right)$ decreases clearly from the zoea I to the megalopa instar, whereas respiration (Fig. 19), excretion (Fig. 20), and exuvial losses increase in the same order. Net growth efficiency $\left(K_{2}\right)$ decreases in carbon from 0.63 (zoea I) to 0.29 (megalopa), and in nitrogen from 0.76 to 0.45 . When exuvia production $\left(G_{E}\right)$ is subtracted from total growth, $G_{T}$-based $K_{2}$ values are obtained (see \% tissue growth in Figs 19, 20). This measure of net growth efficiency decreases in the carbon budget from 0.56 (zoea I) to 0.16 (megalopa), and from 0.72 to 0.38 in the nitrogen budget.

Cumulative carbon and nitrogen budgets for the complete larval development from hatching to metamorphosis are given in Figures 21 and 22. Partitioning of assimilated matter is shown in Figures 23 and 24. The relative proportions of single parameters are in these cumulative budgets intermediate between those found in individual instars. These summary budgets integrate all data from Figures 13 to 20 , and they may be used in comparative studies of carbon and nitrogen budgets in different species of larval decapods.

\section{DISCUSSION}

The uptake and partitioning of nutritional energy by larval stages has been studied in only a few decapod crustacean species (see Dawirs, 1983, and Dawirs et al., 1986, for recent discussion). The temporal resolution of measurements was in most cases too low to detect and analyse variation patterns within individual moult cycles and, so far, no complete carbon or nitrogen budgets for larval decapods have been published. Growth or other bioenergetic aspects were modelled for juvenile crabs (Hartnoll, 1978; Hartnoll \& Gould, 1988), mysids (Clutter \& Theilacker, 1971), euphausiids (Ross, 1982a, b; Stuart, 1986), cladocerans (Lampert, 1977a, b), amphipods (Soldatova, 1970; Dagg, 1976), and 
Ingestion: $636 \mu \mathrm{g} /$ ind
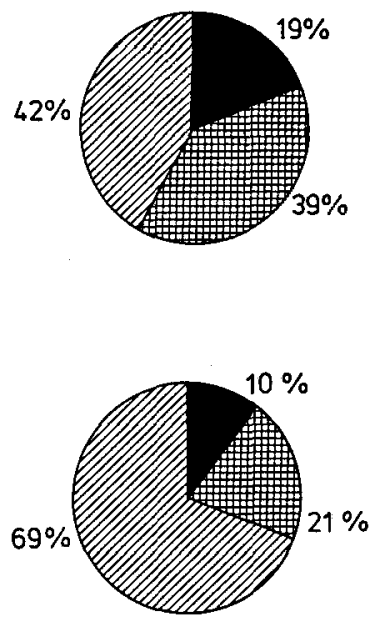

Respiration : $258 \mu \mathrm{g} C /$ ind

=Zoea I
Assimilation: $444 \mu \mathrm{g} /$ ind Total growth: $186 \mu \mathrm{g} C /$ ind
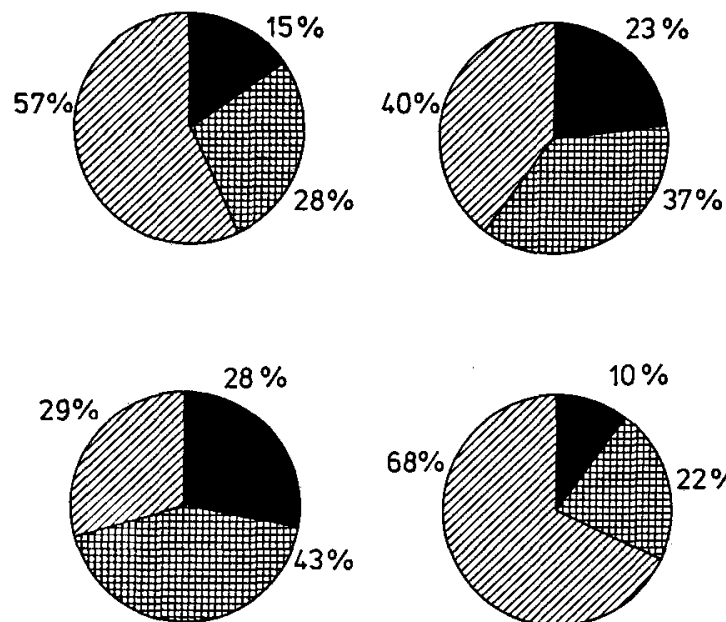

Tissue growth: $134 \mu \mathrm{g} C /$ ind

= Zoea II

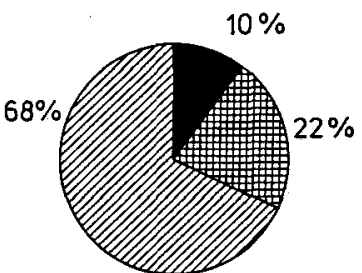

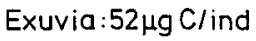

ॠ=Megalopa

Fig. 15. Hyas araneus, carbon (C) budget. Contribution (\% of cumulative $\mathrm{C}$ values for complete larval development) by individual larval instars

Ingestion: $119.1 \mu \mathrm{g} /$ ind
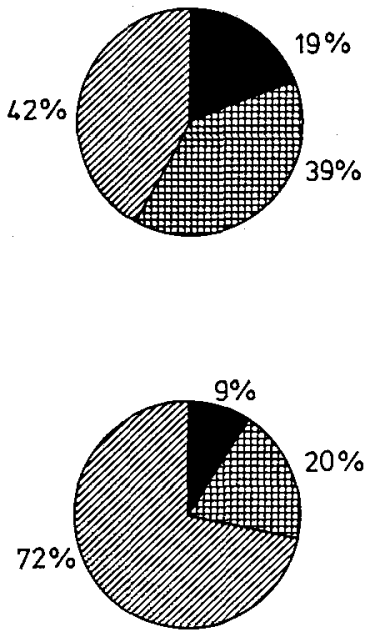

Excretion: $28.3 \mu \mathrm{gN} / \mathrm{ind}$

E= Zoea I
Assimilation : $63.6 \mu \mathrm{g} \mathrm{N} / \mathrm{ind}$
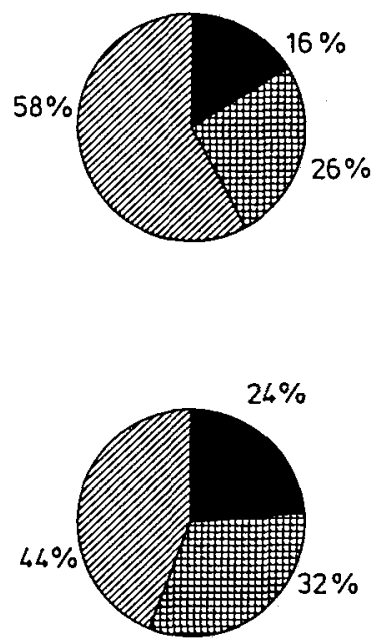

Tissue growth: $31.6 \mu \mathrm{gN} /$ ind

目:Zoed II
Total growth: $35.3 \mu \mathrm{gN} / \mathrm{ind}$
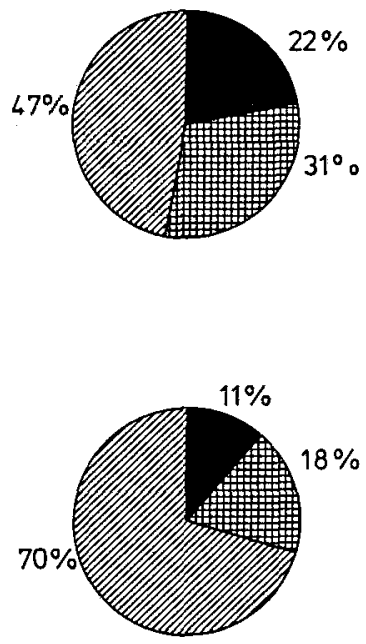

Exuvia: $3.7 \mu \mathrm{gN} / \mathrm{ind}$

$\square=$ Megalopa

Fig. 16. Hyas araneus, nitrogen (N) budget. Contribution (\% of cumulative $\mathrm{N}$ values for complete larval development) by individual larval instars 


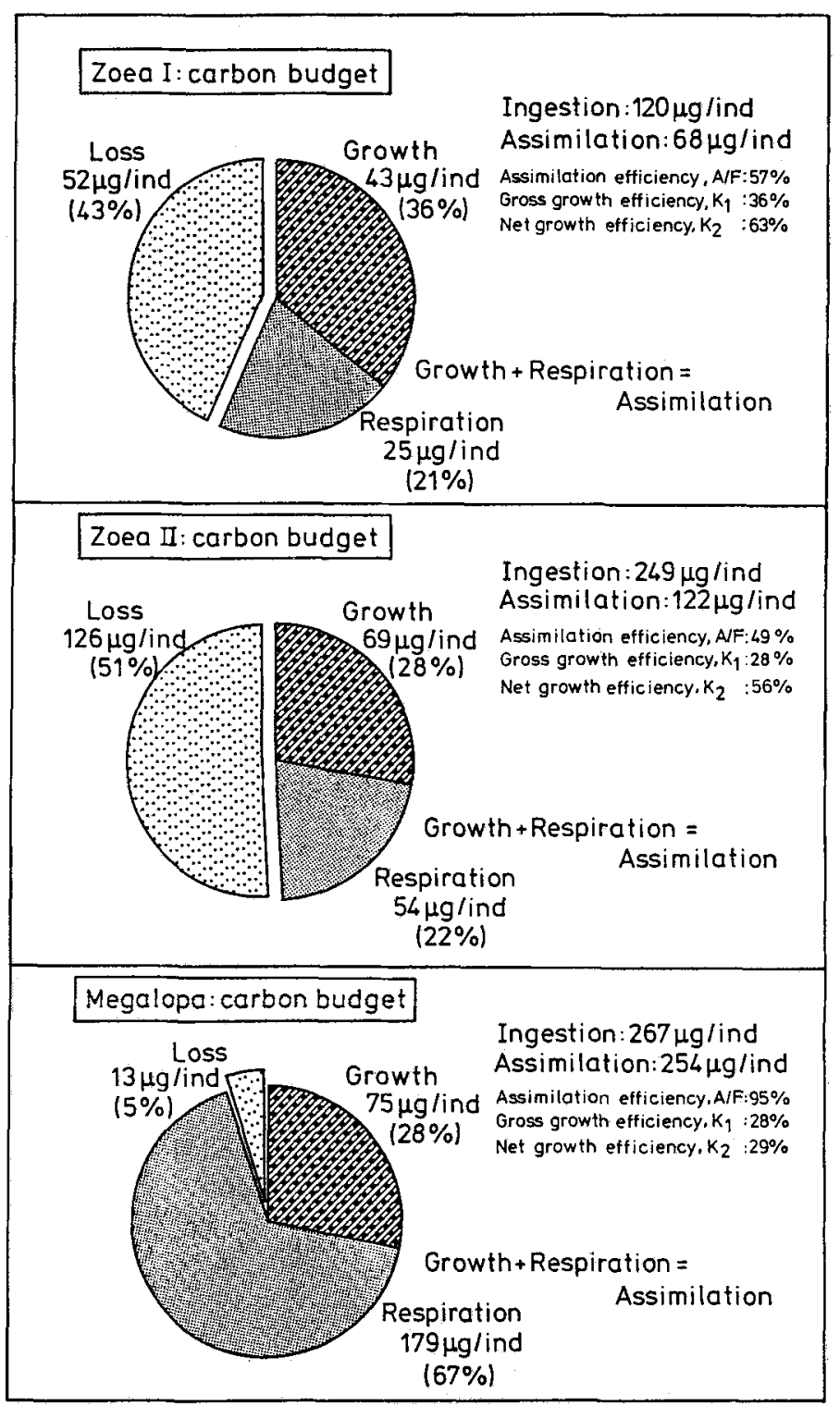

Fig. 17. Hyas araneus, larval instars, carbon (C) budget. Partitioning ( $\mu \mathrm{g} \cdot \mathrm{C} \cdot$ individual $^{-1} ; \%$ ) of ingested $C$ (cumulative values; cf. Fig. 13) among growth (G), respiration $(R)$, and loss $(L)$; cumulative assimilation efficiency $(A / F)$, gross growth $\left(K_{1}\right)$ and net growth efficiency $\left(K_{2}\right)$ (in \%) 


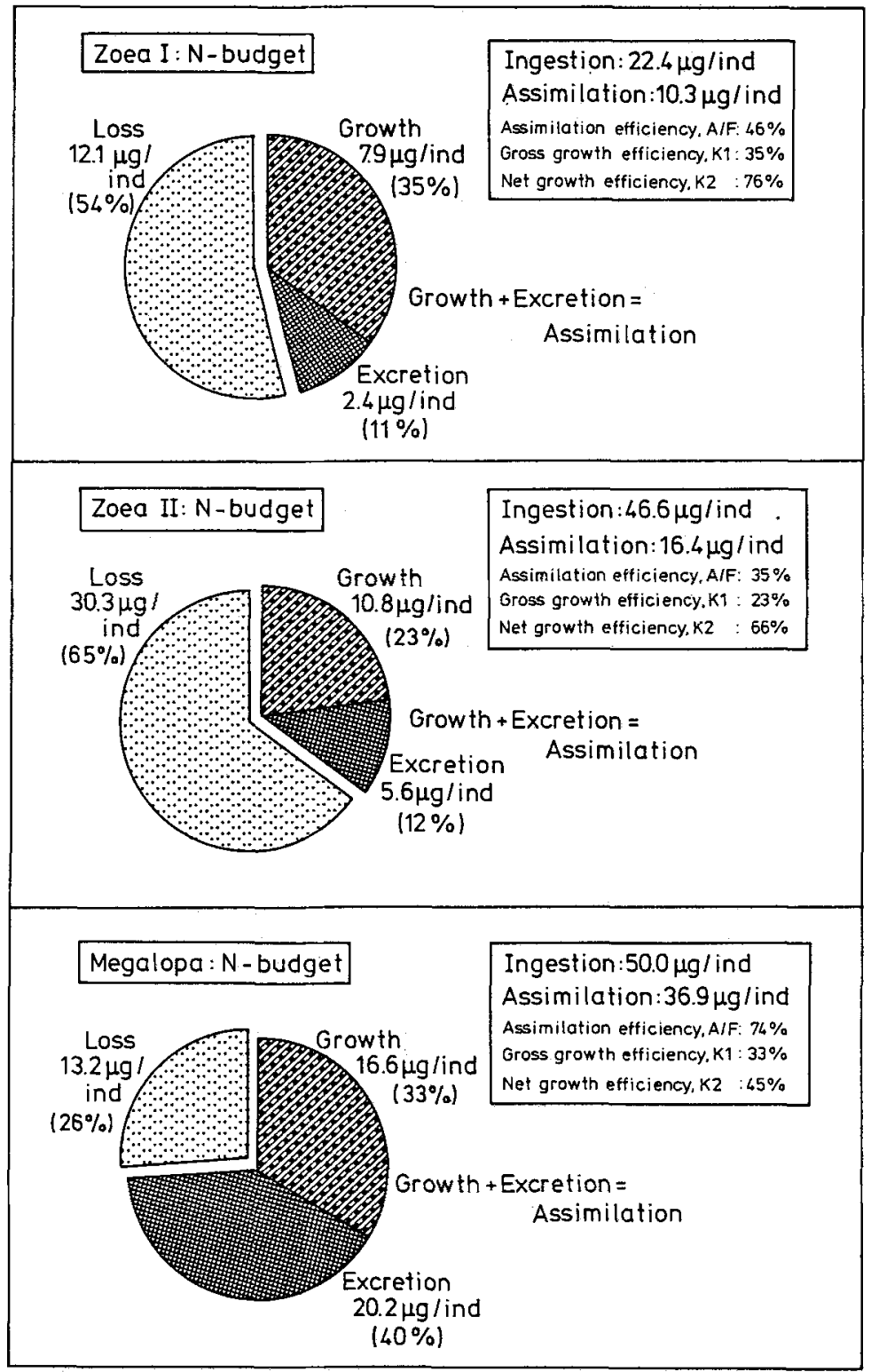

Fig. 18. Hyas araneus, larval instars, nitrogen $(\mathrm{N})$ budget. Partitioning ( $\mu \mathrm{g} \mathrm{N} \cdot$ individual $\left.^{-1} ; \%\right)$ of ingested $N$ (cumulative values; cf. Fig. 14) among growth (G), excretion (U), and loss (L); cumulative assimilation efficiency $(A / F)$, gross growth $\left(K_{1}\right)$ and net growth efficiency $\left(K_{2}\right)$ (in \%) 


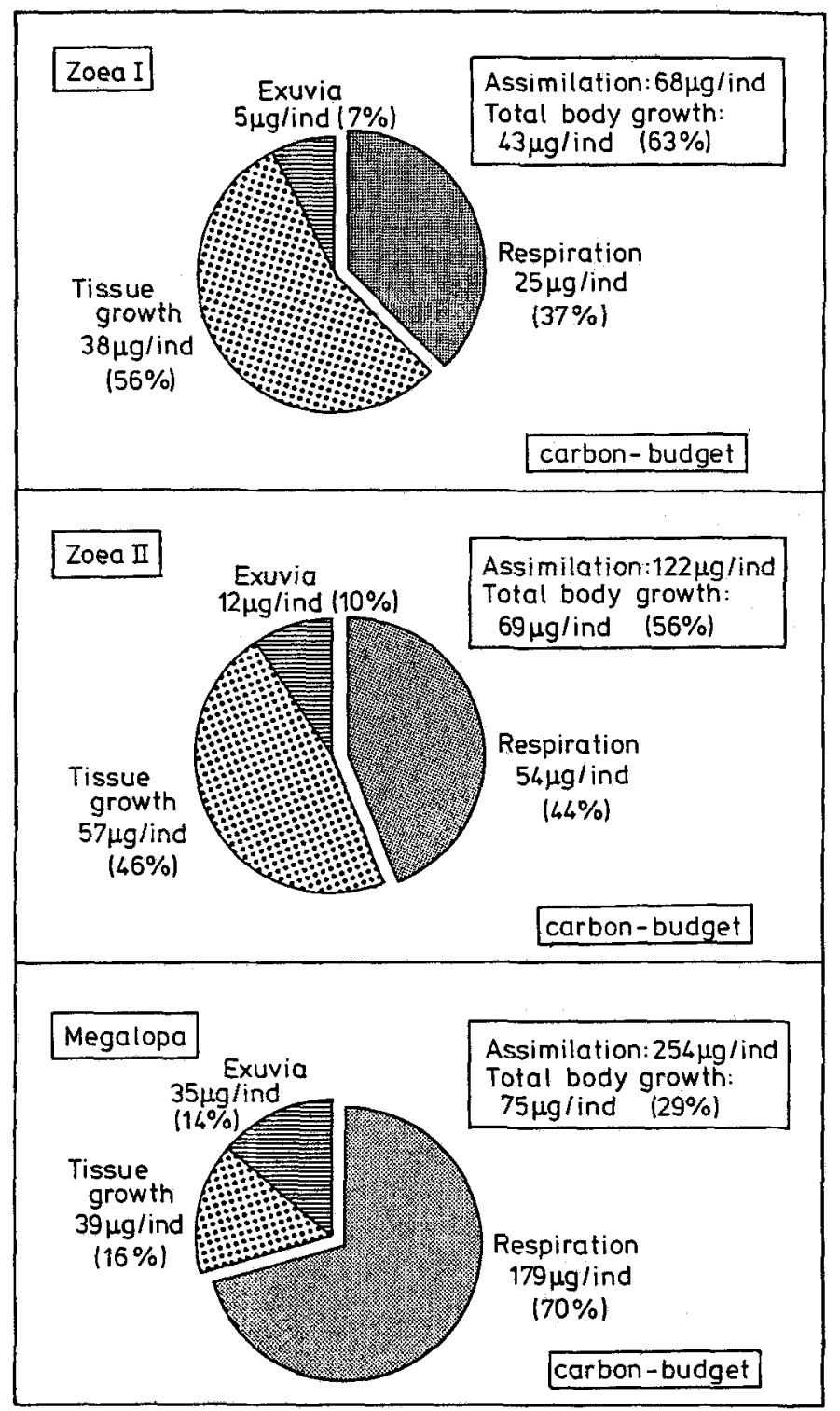

Fig. 19. Hyas araneus, larval instars, carbon $(C)$ budget. Partitioning $\left(\mu \mathrm{g} C \cdot\right.$ individual $\left.^{-1} ; \%\right)$ of assimilated $\mathrm{C}$ (cumulative values; cf. Fig. 13) among tissue growth $\left(G_{T}\right)$, exuvia production $\left(G_{E}\right)$, and respiration $(R)$ 


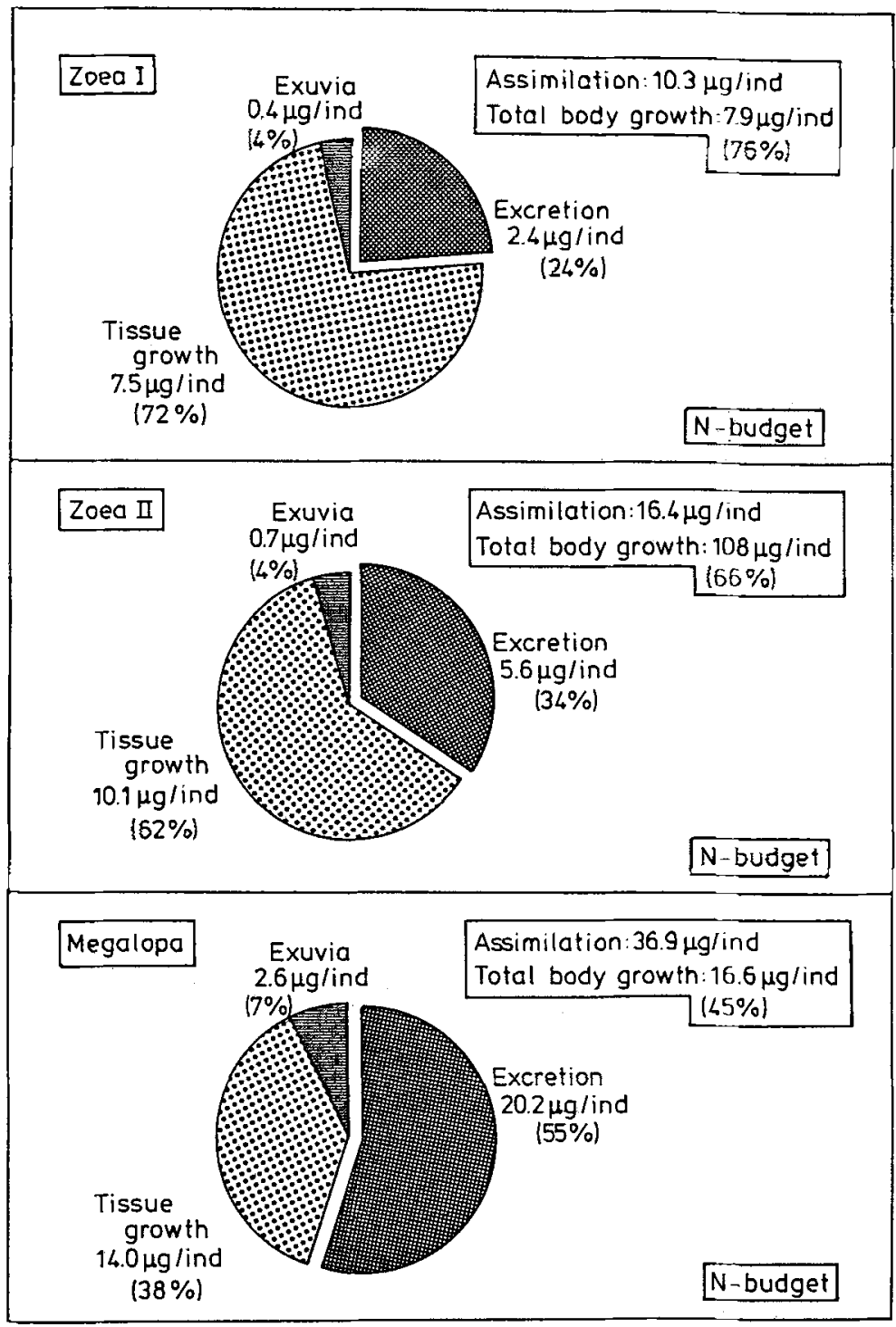

Fig. 20. Hyas araneus, larval instars, nitrogen $(\mathrm{N})$ budget. Partitioning ( $\mu \mathrm{g} \mathrm{N} \cdot$ individual $\left.^{-1} ; \%\right)$ of assimilated $N$ (cumulative values; cf. Fig. 14) among tissue growth $\left(G_{T}\right)$, exuvia production $\left(G_{E}\right)$, and excretion $(U)$ 


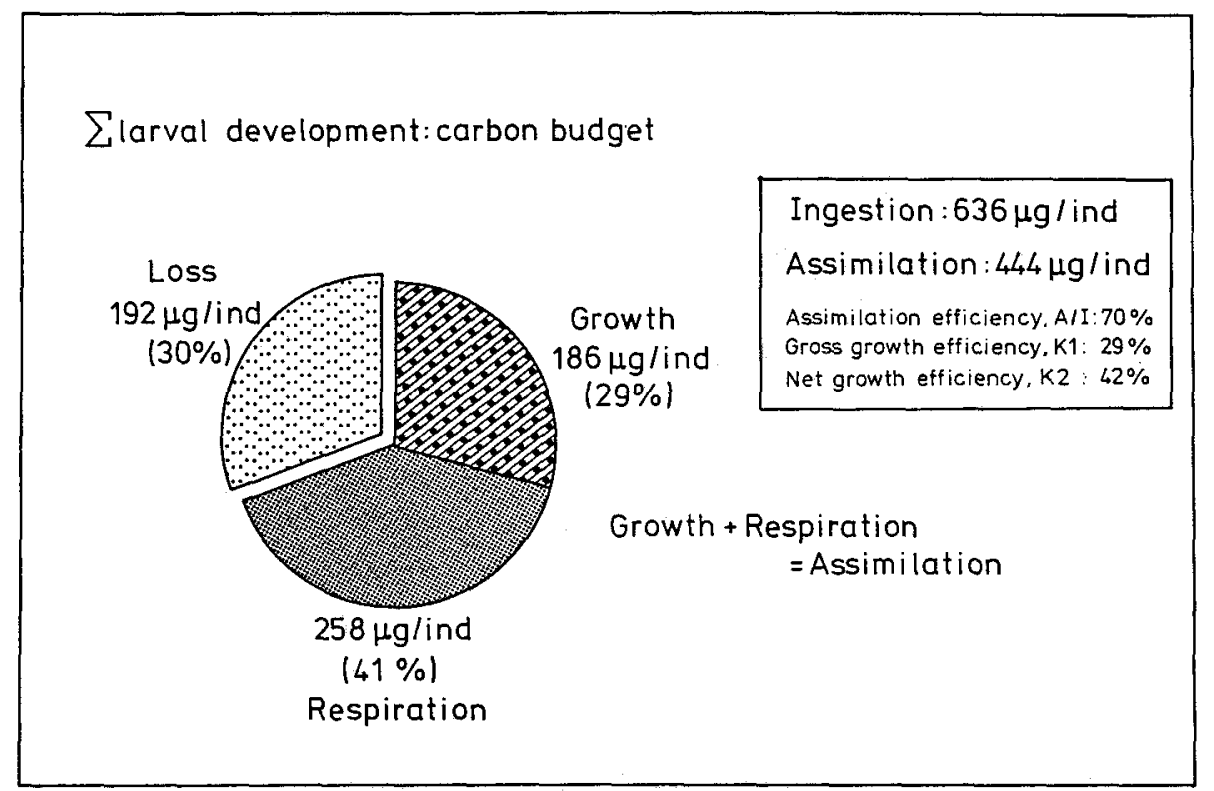

Fig. 21. Hyas araneus, complete larval development, carbon (C) budget. Partitioning ( $\mu \mathrm{g} \mathrm{C} \cdot \mathrm{in}$ dividual $^{-1} ; \%$ ) of totally ingested $C$ among growth $(G)$, respiration $(R)$, and loss (L); cumulative assimilation efficiency $(A / F)$, gross growth $\left(K_{1}\right)$ and net growth efficiency $\left(K_{2}\right)$ (in \%)

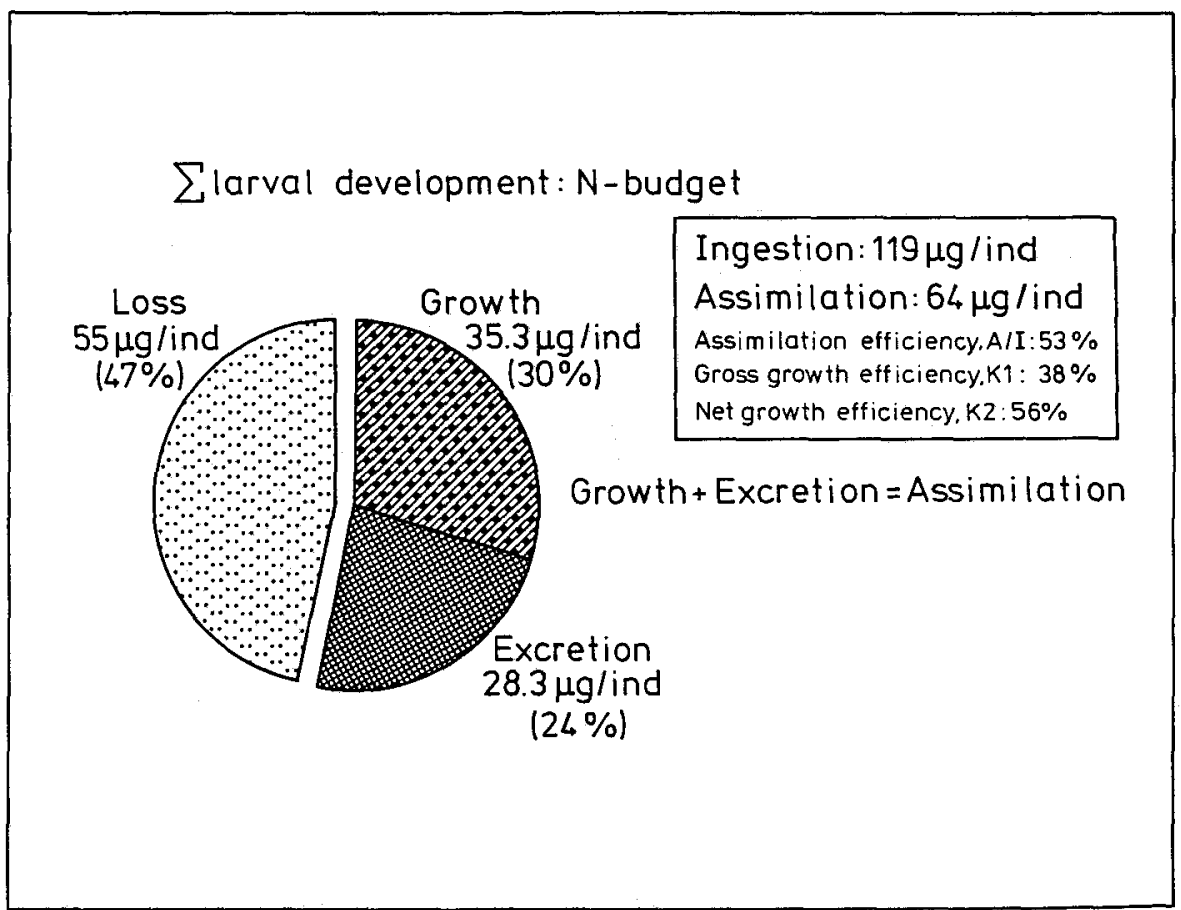

Fig. 22. Hyas araneus, complete larval development, nitrogen budget. Partitioning ( $\mu \mathrm{g}$ - individual $^{-1} ; \%$ ) of totally ingested $N$ among growth $(G)$, excretion $(U)$, and loss $(L)$; cumulative assimilation efficiency $(A / F)$, gross growth $\left(K_{1}\right)$ and net growth efficiency $\left(K_{2}\right)$ (in \%) 


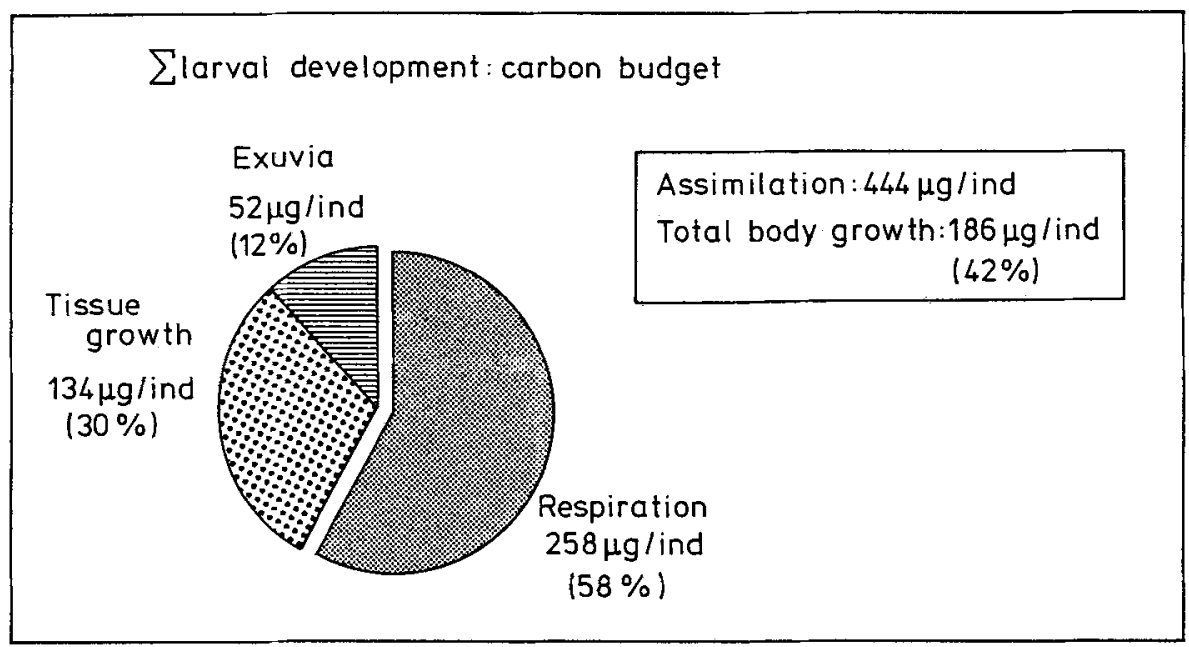

Fig. 23. Hyas araneus, complete larval development, carbon $(\mathrm{C})$ budget. Partitioning $(\mu \mathrm{g} \mathrm{C} \cdot$ individual $^{-1} ; \%$ ) of totally assimilated $\mathrm{C}$ among tissue growth $\left(G_{T}\right)$, exuvia production $\left(G_{E}\right)$, and respiration $(R)$

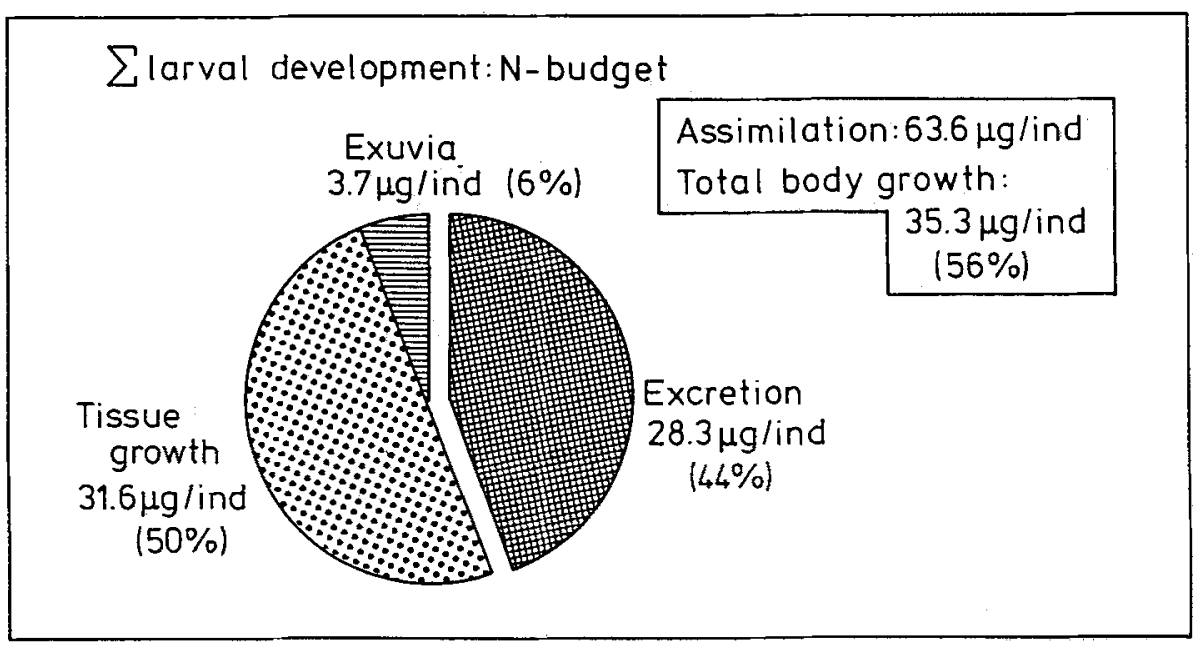

Fig. 24. Hyas araneus, complete larval development, nitrogen ( $N$ ) budget. Partitioning $(\mu \mathrm{g} \cdot \mathrm{N}$ individual $\left.{ }^{-1} ; \%\right)$ of totally assimilated $N$ among tissue growth $\left(G_{T}\right)$, exuvia production $\left(G_{E}\right)$, and excretion $(U)$ 
fish (Durbin \& Durbin, 1983; Bartell et al., 1986), but not for brachyuran larvae. Thus, the present bioenergetic model and its implications are difficult to discuss at present, as no comparable data on other larval decapods is available yet. However, there are some more or less complete budgets of carbon or nitrogen in adult decapods and other crustaceans, where comparisons with Hyas araneus are possible.

For technical reasons, all figures of ingestion $(F)$ and loss $(L)$ must be considered relatively inaccurate (compared to growth, exuviation, respiration, and excretion measurements): decapod larvae often reveal a rather inefficient feeding behaviour that has been observed also in some insect larvae (Johnson et al., 1975) and in carnivorous copepods (Ikeda, 1977), where it was termed "wasteful killing" or "over-hunting", respectively. This incomplete ingestion of killed prey, together with leaching of liquid and small particulate materials from food during the feeding process (see Dagg, 1974, and Pechenik, 1979, for discussion) leads to practically uncontrollable losses and, thus, reduces also the accuracy of ingestion rate measurements. A direct determination of $L$ was not conducted in this study, as it is extremely difficult and unreliable in small aquatic animals such as crab larvae. Therefore, this part of the budget remains somewhat uncertain.

Patterns of variation in absolute (per individual) parameters of the $\mathrm{C}$ and $\mathrm{N}$ budgets $(F, G, R, U)$ measured in individual larval moult cycles were recently discussed in detail by Anger et al. (1989). Our model is derived from the same data and, hence, describes the same patterns of change during larval development (Figs 1 to 4).

Specific (C and N-related) parameters (Figs 5,6 ) may be compared with some data from the literature. The present model predicts conspicuous variation in specific feeding and growth rates during the course of individual moult cycles, whereas specific respiration and excretion rates remain relatively constant. $F / C$ and $F / N$ may reach maximum values (in zoeal postmoult stages) of ca $40 \%$ and $30 \%$ of biomass $\mathrm{C}$ and $\mathrm{N}$ per day, respectively. In shrimp larvae with a comparable $C$ content, Omori (1979) measured $F / C$ values between 30 and $60 \%$. Similar values were found in a previous study with H. araneus larvae (Anger \& Dietrich, 1984). In euphausiids feeding on Artemia, Stuart (1986) found C-specific ingestion rates of ca 21 to $22 \%$. These figures are similar to average $F / C$ in the zoeal instars (ca 25 and $20 \%$ ) but higher than in the megalopa of $H$. araneus (ca $5 \%$ ). When specific feeding rates of another larval crab, Carcinus maenas, are calculated from published growth (Dawirs et al., 1986) and ingestion rates (Dawirs \& Dietrich, 1986), far higher values ( $>100 \%$ ) are obtained. Such high specific feeding rates had been observed in some mysidaceans and planktonic copepods (for references see Conover, 1978, and Toda et al., 1987), but not in brachyuran larvae. This discrepancy may in part be explained by an over-estimation of Fin Dawirs' and Dietrich's paper, but it may be caused also by the very small size of $C$. maenas larvae: many studies (e.g. Omori, 1979; Sedgwick, 1979; Ross, 1982a; Anger \& Dietrich, 1984; Pfaffenhöfer \& Orcutt, 1986; Toda et al., 1987) suggest that specific feeding rates decrease in general with increasing biomass. According to the present model (Figs 5,6 ) as well as data given by Dawirs et al. (1986) and Dawirs \& Dietrich (1986), this applies also to growth during individual moult cycles of crab larvae.

Specific growth rates of $H$, araneus larvae are in general higher in $\mathrm{C}$ than in $\mathrm{N}$, and they decrease during growth and development, i.e. during individual moult cycles and in subsequent instars (Figs 5,6). Similar patterns were found in hermit crab zoeae, where 
G/C and G/N values mostly varied between ca 4 and $14 \% \cdot \mathrm{d}^{-1}$ (Anger, 1989). Stephenson \& Knight (1980) used an exponential model of growth that predicted in prawn larvae a constant weight gain of approximately $8 \%$ per day. This value is similar to those reported by Mootz \& Epifanio (1974) for larval brachyurans and Logan \& Epifanio (1978) for lobsters. Also Incze et al. (1984) and Lindley (1988) assumed constant growth rates of decapod larvae in estimates of field production. However, Ross (1982a) tested and rejected in euphausiids the hypothesis that specific growth rate is a constant. She found clearly decreasing $G / C$ and $G / N$ rates with increasing biomass. This pattern is in agreement with the predictions of the present model (Figs 5,6) and with many further observations on growth in crustaceans and other marine animals (e.g. Childress \& Price, 1983; Dawirs et al., 1986; Anger, 1989; Anger et al., 1989).

Decreasing specific growth rates during development and growth may in part be explained by concurrently decreasing specific feeding rates (see above); however, relatively constant specific respiration and excretion rates (Figs 5,6 ) suggest that there is also a shift in energy partitioning. This is particularly conspicuous in the metabolic coefficient (Fig. 7), and it is further reflected in gross and net growth efficiencies (see below).

Carbon-specific respiration rates found at $12{ }^{\circ} \mathrm{C}$ in spider crab larvae average ca $5 \%$ of body $\mathrm{C}$ per day (Fig. 5). This is similar to $R / C$ values found at similar temperatures in mysidaceans with a comparable biomass (Toda et al., 1987). Like specific excretion rates, they appear rather constant compared to specific daily feeding and growth rates (Figs 5 , 6); however, moult-cycle related and other developmental variations do occur also in these parameters (Anger et al., 1989). Their patterns of variation are in all larval instars of $H$. araneus inverse to each other, with maximum specific excretion and minimum respiration in intermoult and early premoult (approximately stages $C$ to $D_{0}$ ). Hence, a maximum atomic $\mathrm{O} / \mathrm{N}$ ratio was found near ecdysis (postmoult, late premoult), and a minimum in intermoult and early premoult (Anger et al., 1989). The only comparable data available for other larval decapods (Sasaki et al., 1986) reveal a similar pattern, although not so clearly. This possible general pattern in the $\mathrm{O} / \mathrm{N}$ ratio suggests that larvae metabolize proportionally more lipids and/or carbohydrates near ecdysis, but more protein in the middle of the moult cycle. In adult decapods, carbohydrate-oriented metabolism increases during the premoult stages, when parts of the old cuticle are resorbed and a new cuticle is secreted (e.g. Speck \& Urich, 1971, 1972; Spindler-Barth, 1976). Unfortunately, no comparably detailed studies of larval biochemistry in relation to the moult cycle are available at present. In subsequent larval instars of $H$. araneus, the average O/N ratio decreases (Anger et al., 1989). The same tendency was found in larval lobsters (Sasaki et al., 1986) and crabs (Mootz \& Epifanio, 1974; Johns, 1982). In mud crab larvae, Levine \& Sulkin (1979) measured extremely low O/N ratios, which suggests an overestimation of ammonia excretion.

Since the relation between biomass accumulation (i.e. growth) and metabolic and excretory losses shifts during larval development of $H$. araneus towards greater losses, gross and net growth efficiencies reveal clearly decreasing tendencies in this species (Figs 8, 9). Calow (1977) reviewed net growth efficiencies in developing animals and found in general a clearly decreasing trend that approaches and (in adults) reaches zero. A decreasing $K_{2}$ with increasing biomass was found also in shore crab larvae (Dawirs, 1983), larval and juvenile prawns (Reeve, 1969; Sedgwick, 1979), euphausids (Ross, 
1982b), and amphipods (Soldatova, 1970). However, in some larval decapods increasing $K_{2}$ values were measured (Mootz \& Epifanio, 1974; Levine \& Sulkin, 1979; Stephenson \& Knight, 1980; Johns, 1982).

Welch (1968) and Conover (1978) found assimilation efficiency of aquatic consumers negatively correlated, in general, with net growth efficiency. This trend is consistent with the observation that the zoeal instars of $H$. araneus show low $A / F$ but high $K_{2}$ values, whereas the megalopa shows an opposite relationship (Figs 17, 18). However, changes during individual larval moult cycles do not show correlations between $A / F$ and either $K_{2}$ or $K_{1}$. In the zoeal instars, $A / F$ may be negatively correlated with feeding rates (Figs 8,9 ). In general, the search for possible correlations between individual parameters of the $\mathrm{C}$ and $\mathrm{N}$ budgets was not very successful (cf. Fig. 11). Some apparent correlations may occur in the zoeal instars, however, they could be caused by parallel variations in pairs of energetic parameters that are regulated independently by a third variable, i.e. the moult cycle. In the megalopa, it becomes obvious that these parameters may in principle be independent (Fig. 11). This does not exclude a possible existence of direct relationships between individual budget parameters, at least in the zoeal instars, but at present there is no evidence for them.

In $K_{1}$ of the zoeal instars of $H$. araneus, Anger \& Dietrich (1984) observed a variation pattern that was very similar to that predicted by the present model (derived from another data set). Also in $K_{2}$ of the megalopa instar, changes similar to simulated curves (Figs 8,9 ) had been obtained (Anger, 1987). This correspondence suggests that the model yields rather realistic predictions of moult-cycle related changes in the partitioning of $\mathrm{C}$ and $\mathrm{N}$ in $H$. araneus larvae reared under constant conditions in the laboratory. However, further data with high temporal (i.e. developmental) resolution are necessary to allow generalisations about developmental changes in bioenergetic traits of decapod larvae.

The data available at present suggest that, at least in $H$. araneus larvae, the early moult cycle stages (postmoult, early intermoult) are the most efficient in terms of food conversion. This is more conspicuous in $C$ than in $N$ (Figs 8,9) and hence, more in lipid than in protein (Fig. 10). Carbon assimilation efficiency is in the zoeal instars relatively high also in the premoult phase, but most of the $C$ assimilated in these late stages is expended in heat production, i.e. lost in respiration. In adult crustaceans, most of the energy and matter needed for ecdysis may be provided by resorption of old cuticle materials (Speck \& Urich, 1971, 1972). This is probably true also for euphausiids, whereas larval decapods apparently are not able to resorb a high percentage of the old exoskeleton (see Anger, 1984, for recent discussion). The amounts of $\mathrm{C}$ and $\mathrm{N}$ lost by exuviation increase significantly in subsequent instars (Figs 13,14), also in relation to tissue growth (Figs 19, 20). However, 22-24\% of the carbon lost with the shed exoskeleton is actually inorganic (in contrast to only $1-3 \%$ in total body C; Anger, 1984). Thus, exuvial energy losses are lower than the corresponding carbon losses. The latter may reach a maximum (in the megalopa instar) of $14 \%$ of assimilated $C$ and $47 \%$ of total growth (Fig. 19). Nitrogen losses by exuviation are much lower, reaching a maximum of $7 \%$ of $A$ and $16 \%$ of $G$ (Fig. 20).

The overall partitioning of carbon and nitrogen shows some conspicuous tendencies, when subsequent larval instars are compared with each other (Figs 13 to 20). $A / F$ is in general higher in $C$ than in N. The same pattern was found by Nelson et al. (1977) in juvenile prawns, indicating higher conversion of lipid and/or carbohydrates than of 
protein. Loss of ingested material by defaecation and leaching seems to be very little in the megalopa as compared to the zoeal instars (Figs 17, 18); however, this is probably caused by an inaccuracy (underestimation) of $L$ in the final larval instar (see above; cf. Anger et al., 1989, for discussion), which would cause an overestimation of $A / F$. Very high assimilation and gross growth efficiencies were found also in late larval instars of a barnacle species (Harms, 1987). Since the cypris larva does not eat, these high efficiencies in the preceding naupliar instars may be important for its survival.

The zoeal instars convert assimilated $\mathrm{C}$ and $\mathrm{N}$ with high efficiencies to biomass, whereas the megalopa reveals great metabolic (both respiratory and excretory) losses. These changes in the $\mathrm{C}$ and $\mathrm{N}$ budgets may be related to behavioural and ecological changes that take place before and during metamorphosis. The zoeal instars ingest and convert during their pelagic life high amounts of matter and energy, and most of the assimilated matter is stored in biomass reserves. Thus, the zoeal instars may be considered "feeding stages" of spider crab development, corresponding to the naupliar instars in cirripedes. During this phase, growth has priority over morphogenesis. The uptake of food decreases significantly during the final larval instar (Figs 1,2), also the assimilation and conversion of ingested matter to biomass (Figs 8 to 10). This decline in growth efficiency is independent of temperature (Anger, 1987). In the megalopa, morphogenesis and habitat selection apparently have priority over biomass accumulation. Thus, this instar may be called the "settling stage" of development, corresponding to some degree with the barnacle cypris. This change in bioenergetic strategy is even more conspicuous in hermit crabs (Pagurus bernhardus), where the megalopa develops exclusively with reserves accumulated during the preceding zoeal development (Dawirs, 1981, 1984; Anger, 1989), i.e. it fully corresponds here to the cypris. This extreme shift in energy partitioning ("secondary lecithotrophy": Anger, 1989), from active tissue growth toward exclusive settling activity and metamorphosis, can be explained by an extreme degree of habitat specialization: the dependence on, a mollusc shell or, in cirripedes, on a hard bottom in a particular tidal level. Portunid crabs, in contrast, reveal very high growth rates also in the megalopa instar (Dawirs, 1983; Dawirs et al., 1986), possibly indicating a rather opportunistic settlement pattern in swimming crabs. The spider crab megalopa appears intermediate between these two extreme strategies.

Too few complete budgets of energy or matter in crustacean larvae are at present available to discern possible general tendencies in life cycle strategies of different taxa. Besides more comparative studies, more data on the influence of internal (developmental, moult-cycle related) and external (ecological) factors such as temperature and food are needed to achieve ecologically meaningful models of the ontogeny of crustacean bioenergetics.

Acknowledgements. This paper summarizes results of studies that have been conducted during the past decade. These investigations were supported by the Deutsche Forschungsgemeinschaft (DFG; grant nos.: An 145-1, 2). Many colleagues contributed during these years with discussions, occasional help, and technical assistance, respectively, to the eventual construction of a bioenergetic model of larval development in Hyas araneus: Prof. Dr. H.-P. Bulnheim, Dr. R. R. Dawirs, Dr. J. Harms, Dr. H.-J. Hirche, C. Püschel, B. Köhn, B. Seeger, F. Schorn. 


\section{LITERATURE CITED}

Anger, K, 1984. Gain and loss of particulate organic and inorganic matter in larval and juvenile spider crabs (Hyas araneus) during growth and exuviation. - Helgoländer Meeresunters. 38, $107-122$.

Anger, K., 1987. Energetics of spider crab Hyas araneus megalopa in relation to temperature and the moult cycle. - Mar. Ecol. Prog. Ser. 36, 115-122.

Anger, K., 1989. Growth and exuvial loss during larval and early juvenile development of the hermit crab Pagurus bernhardus, reared in the laboratory. - Mar. Biol. 103, 503-511.

Anger, K. \& Dietrich, A., 1984. Feeding rates and gross growth efficiencies in Hyas araneus L, larvae (Decapoda: Majidae). - J. exp. mar. Biol. Ecol. 77, 169-181.

Anger, K., Harms, J., Püschel, C. \& Seeger, B., 1989. Physiological and biochemical changes during the larval development of a brachyuran crab reared under constant conditions in the laboratory.Helgoländer Meeresunters. 43, 225-244.

Bartell, S. M., Breck, J. E., Gardner, R. H. \& Brenkert, A. L., 1986. Individual parameter perturbation and error analysis of fish bioenergetic models. - Can. J. Fish. aquat. Sci. 43, 160-168.

Calow, P., 1977. Conversion efficiencies in heterotrophic organisms. - Biol. Rev. 52, 385-409.

Childress, J. J. \& Price, M. H., 1983. Growth rate of the bathypelagic crustacean Gnathophausia ingens (Mysidacea: Lophogastridae). II. Accumulation of material and energy. - Mar. Biol. 76 . 165-177.

Clutter, R. I. \& Theilacker, G. H., 1971. Ecological efficiency of a pelagic mysid shrimp; estimates from growth, energy budget, and mortality studies. - Fish. Bull. U.S. 69, 93-115.

Conover, R. J., 1978. Transformation of organic matter. In: Marine ecology. Ed. by O. Kinne. Wiley, Chichester, 4, 221-499.

Dagg, M. J., 1974. Loss of prey body contents during feeding by an aquatic predator. - Ecology 55 , 903-906.

Dagg, M. J., 1976. Complete carbon and nitrogen budgets for the carnivorous amphipod, Calliopius laeviusculus (Kroyer). - Int. Revue ges. Hydrobiol. 61, 297-357.

Dawirs, R. R., 1981. Elemental composition (C, N, H) and energy in the development of Pagurus bernhardus (Decapoda: Paguridae) megalopa. - Mar. Biol. 64, 117-123.

Dawirs, R. R., 1983. Respiration, energy balance and development during growth and starvation of Carcinus maenas L. larvae (Decapoda: Portunidae). - J. exp. mar. Biol. Ecol. 69, 105-128.

Dawirs, R. R., 1984. Respiratory metabolism of Pagurus bernhardus (Decapoda: Paguridae) megalopa. - Mar. Biol. 83, 219-223.

Dawirs, R. R. \& Dietrich, A., 1986. Temperature and laboratory feeding rates in Carcinus maenas L. (Decapoda: Portunidae) larvae from hatching through metamorphosis. - J. exp. mar. Biol. Ecol. 99, 133-147.

Dawirs, R. R., Püschel, C. \& Schorn, F., 1986. Temperature and growth in Carcinus maenas L. (Decapoda: Portunidae) larvae reared in the laboratory from hatching through metamorphosis. J. exp. mar. Biol. Ecol. 100, 47-74.

Drach, P., 1939. Mue et cycle d'intermue chez les Crustacés décapodes. - Annls Inst. océanogr. Monaco 19, 103-391.

Durbin, E. G. \& Durbin, A. G., 1983. Energy and nitrogen budgets for the Atlantic menhaden, Brevoortia tyrannus (Pisces: Clupeidae), a filter-feeding planktivore. - Fish. Bull. U.S. 81, $177-199$.

Harms, J., 1987. Energy budgets for the larval development of Elminius modestus (Crustacea: Cirripedia). - Helgoländer Meeresunters. 41, 45-67.

Hartnoll, R. G., 1978. The effect of salinity and temperature on the post-larval growth of the crab Rhithropanopeus harrisii. In: Physiology and behaviour of marine organisms. Ed. by D. S. McLusky \& A. J. Berry. Pergamon Press, Oxford, 349-358.

Hartnoll, R. G. \& Gould, P., 1988. Brachyuran life history strategies and the optimization of egg production. In: Aspects of decapod crustacean biology. Ed. by A. A. Fincham \& P. S. Rainbow. Clarendon Press, Oxford, 1-9.

Ikeda, T., 1977. Feeding rates of planktonic copepods from a tropical sea. - J. exp. mar. Biol. Ecol. 29, $263-277$. 
Incze, L. S., Wencker, D. L. \& Armstrong, D. A., 1984. Growth and average growth rates of tanner crab zoeae collected from the plankton. - Mar. Biol. 84, 93-100.

Ivlev, U., 1945. The biological productivity of waters. - Usp. sovrem. Biol. 19, 98-120 (Trans., Fish. Res. Bd Can. 394).

Johns, D. M., 1982. Physiological studies on Cancer irroratus larvae. III. Effects of temperature and salinity on the partitioning of energy resources during development. - Mar. Ecol. Prog. Ser. 8, 75-85.

Johnson, D. M., Akre, B. G. \& Crowley, P. H., 1975. Modeling arthropod predation: wasteful killing by damselfly naiads. - Ecology $56,1081-1093$.

Katavic, I., Tudor, M., Komljenovic, J. \& Ruzic, N., 1985. Changes in the biochemical composition of Artemia salina (L.) in relation to different feeding conditions. - Acta adriat. 26, 123-134.

Lampert, W., 1977a. Studies on the carbon balance of Daphnia pulex de Geer as related to environmental conditions. II. The dependence of carbon assimilation on animal size, temperature, food concentration and diet species. - Arch. Hydrobiol. (Suppl.) 48, 310-335.

Lampert, W., $1977 \mathrm{~b}$. Studies on the carbon balance of Daphnia pulex de Geer as related to environmental conditions. III. Production and production efficiency. - Arch. Hydrobiol. (Suppl.) $48,336-360$.

Levine, D. M. \& Sulkin, S. D., 1979. Partitioning and utilization of energy during the larval development of the xanthid crab, Rhithropanopeus harrisii (Gould). - J. exp. mar. Biol. Ecol. 40, $247-257$.

Lindley, J. A., 1988. Estimating biomass and production of pelagic larvae of brachyuran decapods in western European shelf waters. - J. exp. mar. Biol. Ecol. 122, 195-211.

Logan, D. T. \& Epifanio, C. E., 1978. A laboratory energy balance for the larvae and juveniles of the American lobster Homarus americanus. - Mar. Biol. 47, 381-389.

Mootz, C. A. \& Epifanio, C. E., 1974. An energy budget for Menippe mercenaria larvae fed Artemia nauplii. - Biol. Bull. mar, biol. Lab., Woods Hole 146, 44-55.

Nelson, S. G., Li, H. W. \& Knight, A. W., 1977. Calorie, carbon and nitrogen metabolism of juvenile Macrobrachium rosenbergii (De Man) (Crustacea, Palaemonidae) with regard to trophic position. - Comp. Biochem. Physiol. 58(A), 319-327.

Omori, M., 1979. Growth, feeding, and mortality of larval and early postlarval stages of the oceanic shrimp Sergestes similis Hansen. - Limnol. Oceanogr. 24, 273-288.

Paffenhöfer, G.-A. \& Orcutt, J. D., 1986. Feeding, growth and food conversion of the marine cladoceran Penilia avirostris. - J. Plankt. Res. 8, 741-754.

Pechenik, J. A. 1979. Leakage of ingested carbon by gastropod larvae, and its effect on the calculation of assimilation efficiency. - Estuaries 2, 45-49.

Reeve, M. R., 1969. Growth, metamorphosis and energy conversion in the larvae of the prawn, Palaemon serratus. - J. mar. biol. Ass. U.K. 49, 77-96.

Ross, R. M., 1982a. Energetics of Euphausia pacifica. I. Effects of body carbon and nitrogen and temperature on measured and' predicted production. - Mar. Biol. 68, 1-13.

Ross, R. M., 1982b. Energetics of Euphausia pacifica. II. Complete carbon and nitrogen budgets at $8^{\circ}$ and $12{ }^{\circ} \mathrm{C}$ throughout the life span. - Mar. Biol. 68, 15-23.

Sasaki, G. C., Capuzzo, J. M. \& Biesiot, P., 1986. Nutritional and bioenergetic considerations in the development of the American lobster Homarus americanus. - Can. J. Fish. aquat. Sci. 43, 2311-2319.

Sedgwick, R. W., 1979. Effect of ration size and feeding frequency on the growth and food conversion of juvenile Penaeus merguiensis De Man. - Aquaculture 16, 279-298.

Seidel, C. R., Johns, D. M., Schauer, P. S. \& Olney, C. E., 1982. International study on Artemia. XXVI. Food value of nauplii from reference Artemia cysts and four geographical collections of Artemia for mud crab larvae. - Mar. Ecol. Prog. Ser. 8, 309-312.

Soldatova, L. N., 1970. The energy balance of the amphipod Pontogammarus maeoticus. - Oceanology, Wash. 10,129-138.

Sorgeloos, P., Bossuyt, E., Lavens, P., Leger, P., Vanhaecke, P. \& Versichele, D., 1983. The use of brine shrimp Artemia in crustacean hatcheries and nurseries. In: Handbook of mariculture. Ed. by J. P. McVey. CRC Press, Boca Raton, 1, 71-96.

Speck, U. \& Urich, K., 1971. Quantitative Bedeutung der Reservestoffe für Chitinsynthese, Energie- 
stoffwechsel und osmotische Vorgänge während der Häutung des Flußkrebses Orconectes limosus - Z. vergl. Physiol. 71, 286-294.

Speck, U. \& Urich, K., 1972. Resorption des alten Panzers vor der Häutung bei dem Flußkrebs Orconectes limosus. Schicksal des freigesetzten N-Acetylglucosamins. - J. comp. Physiol. 78, 210-220.

Spindler-Barth, M, 1976. Changes in the chemical composition of the common shore crab, Carcinus maenas, during the molting cycle. - J. comp. Physiol. 105, 197-205.

Stephenson, M. J. \& Knight, A. W., 1980. Growth, respiration and caloric content of larvae of the prawn Macrobrachium rosenbergii. - Comp. Biochem. Physiol, 66 (A), 385-391.

Stuart, V., 1986. Feeding and metabolism of Euphausia lucens (Euphausiacea) in the southern Benguela current. - Mar. Ecol. Prog. Ser. 30, 117-125.

Sumitra-Vijayaraghavan, Kumari, L. K. \& Royan, J. P., 1988. Food conversion by Penaeus monodon (Fabricius) fed on decapsulated cysts of Artemia. - Ind. J. mar. Sci. 17, 172-173.

Toda, H., Arima, T., Takahashi, M. \& Ichimura, S., 1987. Physiological evaluation of temperature effect on the growth process of the mysid, Neomysis intermedia Czerniawsky. - J. Plankt. Res. 9, 51-63.

Warren, C. E. \& Davis, G. E., 1967. Laboratory studies on the feeding, bioenergetics, and growth of fish. In: The biological basis of freshwater fish production. Ed. by S. D. Gerking. Wiley, New York, 175-214.

Watanabe, T., Kitajima, C. \& Fujita, S., 1983. Nutritional values of live organisms used in Japan for mass propagation of fish: a review. - Aquaculture 34, 115-143.

Weich, H. E., 1968. Relationships between assimilation efficiencies and growth efficiencies for aquatic consumers. - Ecology 49, 755-759. 